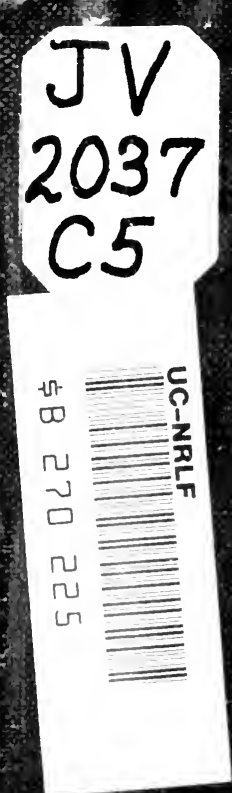



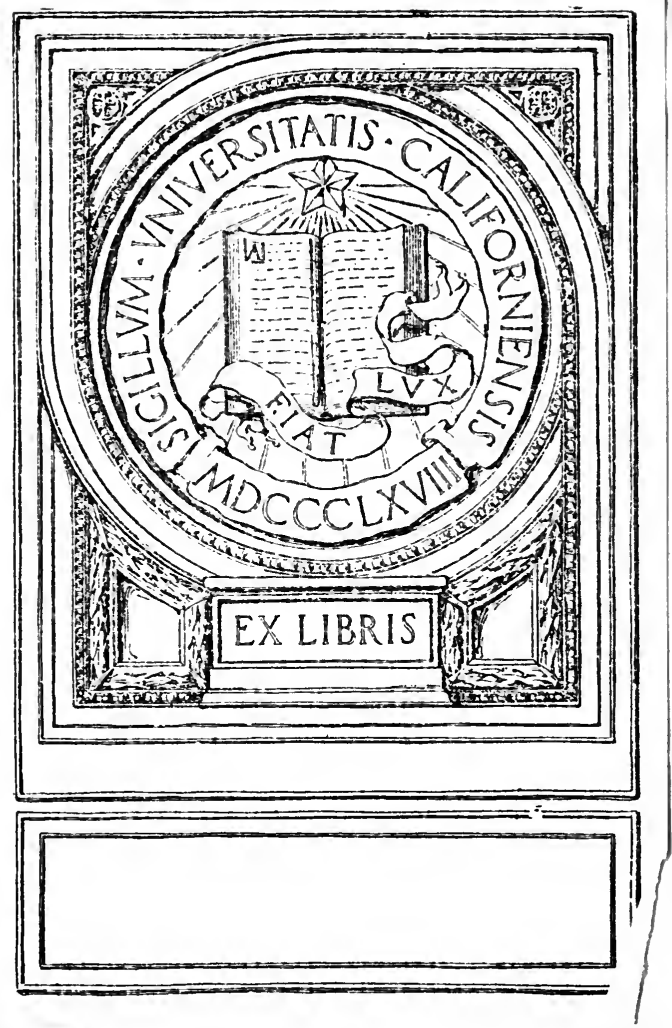


\section{GERMAN COLONIES}


Digitized by the Internet Archive in 2007 with funding from

Microsoft Corporation 


\section{GERMAN COLONIES}

A PLEA FOR THE NATIVE RACES

\section{BY SIR HUGH CLIFFORD}

K.C.M.G., GOVERNOR AND COMMANDER-IN-CHIEF OF THE GOLD COAST

\section{LONDON}

JOHN MURRAY, ALBEMARLE STREET, W. 1918 
$5^{-20^{3}}$
0.5

AII. Rights Rihghted

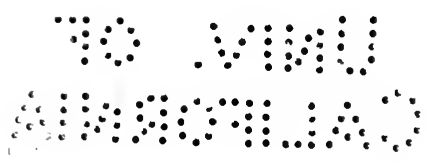




\section{ONTENTS}

I

An urgent problem-The German colonies-Value of German colonies-Germany a bad neighbour-Justice for defenceless peoples.

\section{II}

True and false Imperialism . . . . . pp. 7-8

\section{III}

Good government and Self-government-Democracy and Autocracy-The white man's reign of law-The African-The ideal administrator-Responsibility to the natives pp. 9-15

\section{IV}

Early colonists-Ruthless methods-Magellan-England and Holland-The Dutch East India Company-Portuguese cruelties-English and Dutch rivalry-Dutch successesThe Dutch system-India-Clive's work in India-Empire founded on trade-Hastings' Administration-New methods of government-Protection of the natives-Impeachment of Warren Hastings-Burke and Hastings-British idea of ruling-English ideals . . . . . pp. 16-35

\section{V}

The slave-trade in Africa-The Peace of Utrecht-The Germans at St. Thomas-English and French in Africa-England and the slave-trade-The national conscience-Slave-trade assailed-Denmark, France and Sweden-England takes the lead-England's action-Napoleon's opinion-Progress of British colonies-Force of public opinion-Might and right .

\section{VI}

The Straits Settlements-Treaty with Holland, 1871-The Dutch in Sumatrq . $. \quad . \quad . \quad$ pp. 51-54

\section{VII}

English and Dutch methods-Monopoly and exclusion pp. 55-57 


\section{VIII}

The Burmese War, 1885-A new era-Germany moves-The scramble for colonies-Uncertain boundaries-Grasping Germany-German methods-Diverse colonial policiesDutch and German systems-German brutality-Despotic rule-German tyranny-Use of torture-Flogging-The German decrees-The "rope end" . . pp. 58-74

\section{IX}

Sleeping sickness-The case of Dagadu-Release of Dagadu pp. 75-78

$\mathrm{X}$

Germans and native women-German patronymics

pp. 79-81

\section{XI}

Migration and the rains-Tribal understanding-The labour question-Germans and native labour-Effect of German methods-Movements of native labour-German "efficiency" . .

\section{XII}

Expropriation of natives-Work or flogging • . pp. 90-92

\section{XIII}

The Herreros-Treatment of Herreros-The Herrero warGerman savagery-The attack on Belgium . pp. 93-98

\section{XIV}

The African native-The German system-Germans as conquerors-"Revolts"-Restrictions on natives-Robbing the natives $\quad . \quad . \quad . \quad . \quad$. pp. 99-105

XV

Native soldiers-More outrages-German indifference

\section{XVI}

pp. 106-109

Principles of colonisation-German intervention-Germans not "white men"-German crimes . . . pp. 110-114

XVII

Questions to be solved 


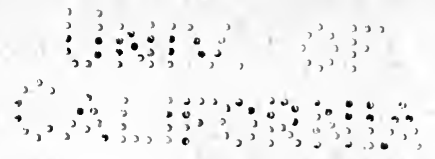

\section{GERMAN GOLONIES}

\section{A PLEA FOR THE NATIVE RACES}

\section{I}

The question of the retention by the Allies or the restoration to Germany of the colonies which the latter has lost, as an immediate consequence of her acts of unprovoked aggression in Europe, is one which will, of course, mainly be determined by the character of the peace eventually secured. Even if the statesmen of Europe and America find themselves at last in a position to dictate terms to Germany, there is a certain danger that they may fail to attach to this matter the importance which rightly belongs to it.

The innumerable intricate problems that will demand solution in Europe will perhaps merit and will certainly receive the first consideration; and as colonial affairs are remote from the experience and do not greatly excite the interest of the electorates of Great Britain, of France, or of the United States, it is to be apprehended that this question may be treated at the peace conference as a mere matter of expediency. Were this to befall, it would amount to a disaster of the first 


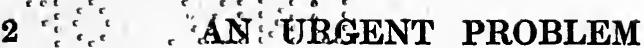

magnituste; for in the idecision to be arrived at principles of vital importance are at stake.

Civilisation, as represented by the democracies of Europe and America, is on its trial in this matter before the whole non-European world. The coloured races are waiting to see whether the importance of their interests is to receive recognition at the hands of the Allies, whether the sense of responsibility of the white nations for the welfare of the peoples of the non-European world is to be proof against the temptation to follow the line of least resistance, whether there is to be established one law for the white races and another for the rest of mankind with regard to the rights of small and defenceless peoples to fair and just treatment, and whether the loyal and often enthusiastic assistance which many of these peoples have afforded to Great Britain and to France in the hour of their need is to be acknowledged or ignored.

It is to be apprehended that the comparatively low intrinsic value of the erstwhile German colonies may be allowed to affect the judgment of the allied statesmen when the question of their fate comes up for decision. With the exception of South-West Africa, no one of these colonies is, in any true sense, a "white man's country."

Even Damaraland and Great Namaqualand, though they contain valuable deposits of diamonds and minerals, and considerable areas suitable for pasturage, are greatly handicapped by the inadequacy of their water-supply. The difficulties which they therefore present to effective colonisation by Europeans are comparable to those 
experienced in Westérn Australia - a country which they in some respects resemble. It remains to be discovered whether their natural wealth will suffice to defray the inevitably heavy cost of their development.

German East Africa and the Cameroons cover extensive areas, enjoy at different altitudes a great variety of climate, are capable of immense development, and are sources whence valuable supplies of raw materials may be drawn. They, however, are not places in which Europeans can permanently reside, or in which the families of white men can successfully be reared.

Togoland shares with them these disabilities; and though it was the only German colony that was able to defray the cost of its own administration, it produces an annual revenue which compares unfavourably with that yielded by a single average district in the neighbouring British Colony of the Gold. Coast. Its real value to Germany was strategical, the great installation at Kamina forming, until its destruction by the Germans in August, 1914, the pivotal point of their overseas wireless system. It constituted the connectinglink between Berlin, on the one hand, and Dares-Salaam in East Africa, and Windhoek, in SouthWest Africa, on the other; and though it was only in existence as a working installation for less than four weeks, it flashed messages across the Atlantic during the first month of the war that warned more than two million pounds' worth of German shipping to take refuge in American ports. 
For the rest, German New Guinea is the home of intractable savages, is unsuitable for the habitation of white men, and is apparently impossible of development with the aid of its native population alone. The colony of Kiao-Chau, which Germany wrested from China, and the islands of the Pacific which she annexed during the concluding years of the nineteenth century, were mainly valued by her because they gave her a firmer position in the politics of the Far East and of Australasia than she otherwise would have occupied, and secured to her a louder voice in discussions arising from them.

No one of these colonial possessions, therefore, is in itself a territory of such value that any other Power need greatly covet it; and this being so, it has been suggested in some quarters that the restoration of her colonies to Germany, while vastly important to her, is a proposal to which the Allies need raise no very strong objection. There is, moreover, a certain body of opinion, even in the allied countries, which favours the view that it would be, in some sort, unfair to exclude Germany from the "place in the sun " of which the, war has deprived her. Others add that such exclusion would be short-sighted, and a grave political mistake. Germany, they argue, being a great nation, must be allowed a sufficient outlet for her surplus energies-must be suffered to resume the position of a World-State which, in common with the other principal European Powers, she occupied before the war; and that to attempt to prevent this would be vindictive and unreason- 
able, and lacking in justification alike on grounds of policy, principle and expediency.

Germany, however, has proved herself a singularly bad and restless neighbour, and the Commonwealth of Australia and the Dominion of New Zealand will have much to say in opposition to any proposal to restore to Germany her former colonies in the Pacific. The Union of South Africa will also bring great pressure to bear to prevent the reversion to Germany of Damaraland and Great Namaqualand; which were conquered by General Botha; while China, which is now one of the Allies, and Japan also, will strenuously resist the reoccupation of Kiao-Chau by Germany.

The fact that no such powerful influences will be arrayed against any proposal that may be made for the restoration of the remaining former possessions of Germany in Africa-German East Africa, the Cameroons and Togoland-renders it all the more probable that the principles that should govern decision in these cases may be obscured and overshadowed by considerations of convenience and expediency. The impression may even be created that something in the nature of an act of

- generosity or of magnanimity will be performed by the Allies if they relinquish all claims to these extensive territories; and as the populations immediately concerned are inarticulate and have no powerful neighbours with direct interests in the matter to come forward as the champions of their cause, this notion may perhaps gain a fairly wide credence.

In this connection, however, it is well to recall 


\section{JUSTICE FOR DEFENCELESS PEOPLES}

the fundamental contentions for a recognition of which the Allies, during the past four years, have been doing strenuous battle. Reduced to their elements they are: firstly, the assertion and vindication of the principle that, in international affairs, right must not be allowed to succumb to mere brute force; and secondly, that justice, fair play, peace and security, must be insured and guaranteed to small and defenceless peoples. It is the purpose of these pages to examine how far the restoration to Germany of her former possessions in Africa is compatible with the establishment of these principles. 


\section{II}

IN his admirable and suggestive work, The Expansion of Europe, Professor Ramsay Muir writes :

The terms " Empire" and "Imperialism" are in some respects unfortunate, because of the suggestion of purely military dominion which they convey; and their habitual employment has led to some unhappy results. It has led men of one school of thought to condemn and repudiate the whole movement, as an immoral product of brute force, regardless of the rights of conquered peoples. They have refused to study it, and have made no endeavour to understand it; not realising that the movement they were condemning was as inevitable and as irresistible as the movement of the tides-and as capable of being turned to beneficent ends. On the other hand, the implications of these terms have perhaps helped to foster in men of another type of mind an unhealthy spirit of pride in mere dominion, as if that were an end in itself, and have led them to exult in the extension of national power, without closely enough considering the purposes for which it was to be used. Both attitudes are deplorable, and in so far as the words "Empire," "Imperial," and "Imperialism" tend to encourage them, they are unfortunate words. They certainly do not adequately express the full significance of the process whereby the civilisation of Europe has been made the civilisation of the world. 
The currency which these descriptive labels have acquired is the more to be regretted at the present time because they savour of " Cæsarism," of despotism, of "shining armour" and of "the mailed fist" - of all the things, in a word, of which the German Kaiser and the aggressive tyranny for which he stands are the appalling culminations. No associations could be more nicely calculated to aifront and antagonise democratic opinion, or to predispose it to distrust any system that has with them even a nominal connection.

This is the very irony of mischance; for if its principles and its purposes were rightly understood, that which, for want of a better name, we call "Imperialism" should make its strongest appeal to those very schools of political thought which to-day incline to decry and suspect it. Unless an attempt be made to grasp those principles and clearly to apprehend those purposes, it is to be feared that the popular judgment may be prejudiced from the outset concerning a question which is of the utmost importance to unnumbered human beings. Of these, in connection with the restoration to Germany or the retention by the Allies of the colonies of East Africa, the Cameroons and Togoland, the fate of some 12,000,000 souls is at this juncture hanging in the balance. 


\section{III}

The late Sir Henry Campbell-Bannerman once stated it to be his opinion that "good government can never be a satisfactory substitute for self-government." $\mathrm{He}$ was at that time the Liberal Prime Minister of Great Britain, and his aphorism succinctly summed up a conclusion at which communities of British stock, at home and abroad, had long ago arrived. It was faith in this deep-rooted conviction, and a confident belief in self-government as the best panacea that can be applied to the grievances of any community of European blood, that led the Government of which Sir Henry Campbell-Bannerman was the head, to grant full autonomy to the Transvaal and to the Orange Free State within four years of the conclusion of hostilities in South Africa. That act was perhaps one of the most daring political experiments in recorded history, and it has been abundantly justified by its results.

It would not be safe to conclude, however, even from so triumphant an object-lesson as this, that the remedy that went so far to heal the recent wounds of a white community in South Africa is equally applicable to the needs of every nonEuropean people. It is well to realise that what we call self-government-viz. any form of government " of the people, by the people, for the people". 
-is the exclusive product of the European character and intellect. In the non-European world it finds its closest counterpart, not among the refined and cultured races of the East, but in the political organisations of certain small and primitive African tribes; but with this very qualified exception, popular control of the executive is a system which is quite foreign to the political conceptions of non-European races. A study of the latter /reveals the fact that their natural genius, throughout the whole of their recorded history, has worked for the establishment of autocratical forms of government, no less certainly than that of the European nations has instinctively aspired toward democratic ideals.

Of this an illuminating modern instance is supplied by the contrast presented by the United States of America and the Republics which occupy the central and southern portions of that continent. The former are peopled by men of European stock, amid whom the negroes form a more or less negligible political minority; and here the system of government that has been evolved is democratic alike in substance, in spirit and in practice. In the republics of Central and Southern America, on the other hand, the proportion of men and women of pure European descent to the rest of the population is very small; and here, though the form of government adopted is democratic, self-government, as it is understood in Europe and in the United States, has never been sought for or attained.

Independence of foreign control, which is quite 
another thing, has been secured; but though they are nominally republics, these States have always been ruled by individual autocrats, such as Diaz in Mexico and Castro in Venezuela, or else by no less autocratical and arbitrary groups and cliques. Revolutions have been common enough, and the number of politicians who have laid claim to the high-sounding title of "The Liberator" almost defies the power of computation; yet these political convulsions have never aimed at anything beyond the transfer of arbitrary powers from one individual or group to another. They have not attempted to control or to modify the character of the authority to be wielded by the victors. In other words, the natural genius peculiar to the European and to the non-European characters respectively, has here asserted itself in each instance, and has produced the form of government which is its distinctive fruit.

Similarly, it is possible to search the long history of Asia without disinterring a single instance of a revolution which was designed to effect a change, not in the personality of the autocrat, but in the autocratical system of his government.

The same may be said to apply to practically all non-European countries; and even the revolutions which the present century has witnessed successively in Persia, in Turkey and in Chinathough each has borrowed much of its inspiration and all its catch-words from the political traditions of the West-have been designed to place the exercise of arbitrary power in new hands, not to limit or to modify the character of the power to 
be exercised. Indeed, these recent political upheavals are chiefly interesting because they show that the leaven of European influence is surely, if slowly working, and because they encourage the hope that more liberal systems of administration may yet be evolved at some future date by some of the non-European nations.

The choice which in the past has lain open to the more politically backward peoples, therefore, has not been a choice between self-government and good-government, for to the former they have never aspired, and the latter, under their own rulers, they have very seldom experienced. Indeed, the bulk of the population has never sought or obtained any effective voice in the matter of their administration, beyond assisting upon occasion to pull down one autocrat and to set up another in his place.

When, therefore, Europeans have intervened in the administration of these countries, the alternative presented to the people has been the unfettered tyranny of native autocrats, on the one hand, and the establishment by a foreign nation of a reign of law, on the other. The choice of the populace has unerringly selected the latter; and though in some places and among the more advanced races of the non-European world the ideal of self-government has dawned, at a later period, upon their consciousness, this has only occurred after the white man's reign of law has first been solidly established, and it is to be recognised as a direct result of association with Euro$\checkmark$ peans and of education upon lines devised by them. 
The most thorough-going advocate of democratic institutions should therefore realise that, in the case of primitive peoples such as those which inhabit German East Africa, the Cameroons and Togoland, unadulterated native rule is not popular or desired by the bulk of the natives. It means the oppression of the weak by the strong, the tyranny of might, the abnegation of law, the performance of various bloody rites, and perennial intertribal strife - in a word, all the things which are most abhorrent to the principles of democracy ; and the only remedy for these anarchical conditions is the imposition from without of an ordered system of jurisdiction based upon justice and equity.

Provided that this actually is the character of the rule established in their midst, the history of the non-European world shows that for the populations immediately concerned, the voice of material advantage is wont to speak in far more persuasive tones than that of racial or national sentiment, the latter being ideas which do not greatly flourish in these regions of the earth. In nearly every instance, experience of European systems of administration makes the native population acquainted with justice and fair treatment for the first time, and the abrupt contrast which these things present to the local methods of government breeds pari passu confidence in the impartiality of the white man and distrust of the administrative capacity of men of their own race.

The work of government, as every practical administrator knows, is mainly a matter of dull, 
painstaking drudgery, and of close attention to detail. It may have its moments of inspiration, of achievement and of success; but save for the professional politician, such moments are of rare occurrence.

Administrative work, if it is to be efficiently and satisfactorily discharged-more especially in the circumscribed arenas of the colonial world, where the rulers and the ruled ordinarily come into very close contact with one another-demands the possession by the administrator of the very qualities which are least frequently found in combination among the indigenous inhabitants of these countries. They are diligence, sustained interest, vigilance, incorruptible purity of official action and intention, indifference alike to popular praise and blame, and-to quote the words of the oath of office which is administered to the Governors of British colonies-a firm determination to "do right by all manner of people, according to law, without fear or favour, affection or ill-will."

These qualities formed no part of the equipment of the native autocrats who ruled these countries before the coming of the white men. They were, save in the matter of diligence and sustained interest, at least as conspicuously absent in the first European exploiters of the nonEuropean world. During the past four hundred years, however, the morality, no less than the civilisation of Europe has made notable advances; and to quote Lord Morley's words :

In respect of territories not self-governing, the 
sense of possession has given place to the sense of obligation, justifying our rule by bringing security, peace and comparative prosperity to lands that never knew them before; here we are fulfilling our mission.

This sense of responsibility toward the native populations of the non-European world was slow in developing among the colonising nations of the West. It owed its inception to British statesmen, and it has since been assiduously cultivated and insisted upon by the people of Great Britain. That is our greatest achievement as a nation in those portions of colonial world which are inhabited by politically backward races, just as in the Dominions the establishment of autonomy is a special feature of British colonial policy.

In order to trace the growth of this sense of obligation and responsibility, it is necessary briefly to recall the circumstances which led to the incursions of the white nations into the nonEuropean world, and the motives whereby, at different periods, the invaders were actuated. 


\section{IV}

European exploration and colonisation, which had their beginning in the fifteenth century, owed their primary impulse to commercial and economic necessity. The free flow of Asiatic merchandise into Europe was stemmed by a double barrier. During the close of the Roman Empire maritime intercourse between the East and the West. had become regular and well-established. Hippalus, a pilot of Greece, for example, was the first who ventured to make use of the monsoons in order to sail across the Indian Ocean; the Periplus of the Erythrean Sea, perhaps the earliest book of sailing directions in the world, shows that many of the seas and ports of the East were well known to the mariners of the West; while in the reign of Claudius, as Pliny records, even from distant Ceylon an embassy found its way to the Court of Rome.

The rise of Muhammadanism in the Middle East in the seventh century cut Europe off from direct commerce with Asia almost entirely for hundreds of years ; and the middleman's monopoly of Asiatic trade, which was established by Venice and shared by other Italian States, enriched those who enjoyed it at the expense of the rest of Christendom. It was the necessity of breaking free from these trammels that set the sea-captains 
and pilots of Prince Henry of Portugal venturing further and further adown the dreadful coast of Africa, that caused Columbus to sail for America, and that impeiled Vasco da Gama, following in the footsteps of John Infante and Bartholomew Diaz, to storm his resolute and choloric way round the Cape of Good Hope.

None the less, both the Spaniards in the New World and the Portuguese in Asia-as became peoples who for generations had suffered many and grievous things at the hands of the Moorswere inspired, not only by a love of adventure and a lust for wealth, but also by a strong religious motive. This is found cropping up in all manner of unlikely people and improbable circumstances; for though the Ten Commandments did not bulk big on their horizon, both nations regarded their invasion of the non-European world in the light of a new and greater Crusade. Their greed, their brutality and their profligacy were unrestrained; yet on occasion-as for instance when Cortes risked the whole success of his great adventure in Mexico by his destruction of the Totonac idols -they were ready to place the cause of their religion before any mere mundane considerations of prudence, policy or material advantage.

For the most part, however, their Christianity served to put a finer edge upon their natural cruelty, rather than to excite in them any feeling of pity or mercy toward the hapless victims of their aggression. Their fanaticism ordinarily supplied them with a moral justification for their least justifiable actions, and the only champions of the 
native populations at this time were the heroic missionary priests, of whom both Spain and Portugal produced a creditable number. Yet even their humanitarianism was the humanitarianism of the sixteenth century, and St. Francis Xavier himself approved the establishment of the Inquisition at Goa.

Thus the expansion of Europe had its beginning in an appalling record of ruthlessness and illdoing. The white men, east and west, proved themselves to be violent, grasping, aggressive folk, who would not live and let live. They claimed not only the best, but the whole. They would not rest contented even with the lion's share, such as the Muhammadans had so long enjoyed of the sea-borne trade of Asia. They respected no rights of person or of property; wherever they were strong enough to enforce it, they insisted upon a monopoly alike of commerce and of power; and in the attainment of their desires they knew neither pity nor scruple. Their only redeeming qualities were the reckless courage which Spaniards and Portuguese alike displayed, and the exalted faith in their mission, as a people chosen of God, whereby even the vilest of the filibusters appear at times to have been inspired.

Until late in the sixteenth century the famous Bull of Alexander VI more or less effectually secured to Spain and to Portugal the monopolies of the discoveries of the West and the East which it respectively conferred upon them. Even the Protestant Powers paid it due regard, not out of reverence for the Papacy, but because at that 
time the political edicts of the Pope constituted the only recognised international law, and European statesmen therefore hesitated to ignore them. It is noteworthy, indeed, that it was the Catholic Powers of Spain and France that were the first respectively to evade and to defy the provisions of the papal decree.

Magellan, who had been present at the taking of Malacca in 1511, had afterwards corresponded with his cousin, Francisco Suraño, who had accompanied the first Portuguese fleet despatched to explore the Spice Islands, and had remained permanently in Ternate and Timor. When, therefore, Magellan offered his services to the King of Spain, he was able to collate the cherished geographical secrets in the possession of both the Iberian nations. This led him to identify the great ocean beyond the American continent, which had been discovered by Balboa in 1511, with the boundless sea that lay, according to native report, to the east of the Moluccas. The existence of a passage round the southern extremity of America was inferred from the analogy of the Cape route to the East, and thus Magellan conceived the tremendous enterprise which has immortalised his name. His ships reached the Spice Islands in 1521, and seven years later the Frenchmen Jean and Raoul Parmentier sailed from Dieppe and penetrated as far east as Sumatra, going and returning round the Cape of Good Hope.

These incursions into their Asiatic preserves, however, did not effect any very material disturbance of the immensely valuable trade monopoly 
enjoyed by the Portuguese, whose apprehensions, for many years after their arrival in the East; were excited solely by the possibility of Turkish reprisals. Had the Muhammadan Powers been able at this juncture to combine, it is probable that they might have regained the mastery of the Indian Ocean of which the Portuguese had deprived them; but the war between Turkey and Egypt rendered any concentration of naval forces in the Red Sea impossible, and the Battle of Lepanto in 1571, by crippling Turkey, put an end for ever to the Muhammadan menace in the eastern seas.

Meanwhile the seamen and merchants of England and Holland had been spending themselves in expeditions the prime object of which was the discovery of a way to the East viâ the north of the American or of the European continents ; and though the Elizabethan adventurers harried the Spanish Main, and Drake circumnavigated the globe and called at the Moluccas in 1577-80, it was not until after the defeat of the Armada in 1588 that any direct and serious challenge was offered by the Protestant nations of western Europe to the ascendency that had been established by their Catholic rivals. The loss of the command of the sea, which Spain and Portugal, now united under the sceptre of Philip II, had suffered, was the determining factor in the situation ; but Dutch and British enterprise was stimulated by the rapid leakage which occurred about this time of the exclusive geographical and other information which these nations possessed, and which they had so long and so jealously guarded. 


\section{THE DUTCH EAST INDIA COMPANY 21}

The Dutch East India Company despatched its first fleet from the Texel, under the command of Cornelius Houtman, in 1595; while the British Company received its first charter at the end of 1599, and began its adventurous career by sending Lancaster on his second raid into the Portuguese East early in the following year. The prime object of both these great commercial corporations was to secure a share of the Asiatic trade, which at that time was infinitely the most valuable in the world.

Whereas the Dutch Company, however, was from the outset a truly national venture, the English Corporation, characteristically enough, was no less distinctively a purely private concern. The statesmen and merchants of Holland felt that in attacking one of the main sources of Spanish wealth they were dealing a heavy blow to their arch-enemy, Philip II ; but though Englishmen, of the generation that had witnessed the defeat of the Armada, may well be supposed to have been animated by similar sentiments, they showed in Asia a far keener interest in commerce than in politics, and as their countrymen in distant lands have since not infrequently experienced, they could not count upon much active support from their Government at home. Moreover, the English Company was desirous of avoiding hostilities where possible, on account of the expense which they entailed, and they grudged money even for purposes of defence, the which, so long as they continued in some sort to co-operate with the Dutch, formed a constant subject of complaint by Holland. 
It is probable that any European nation of the sixteenth century which had enjoyed the opportunities that fate accorded to the Spaniards and the Portuguese would have comported itself toward the native populations which it encountered very much as did these two Iberian peoples. The influx of the Dutch and the English into Asia toward the end of the century marked, however, a distinct improvement in the standard of conduct of white men in the East. This was due to policy, not to any innate moral superiority possessed by the newcomers, the latter being anxious to impress the natives favourably by the adoption of a more friendly and conciliatory attitude.

The Portuguese, by the time that the Dutch and the English arrived upon the scene in force, had suffered severely from the demoralisation that almost inevitably results from a complete emancipation from restraining influences. This had led to the commission by them of every kind of excess, had sown throughout the East a bitter crop of hatred, and had produced a progressive degeneracy that now materially reduced their power of resistance. The "Portugal " found every man's hand against him from one end of Asia to the other; and the Dutch and the English were quick to profit by the situation thus created. By the natives they were at first hailed as deliverers, and the former were eager to enter into alliances with them. Accordingly the great fabric, which the genius, courage and energy of men like Almeida and Albuquerque had reared up and consolidated in little more than a decade and a half, and which 
the folly and the vices of their successors had deeply undermined during the years that followed, collapsed almost at the first assault. The capture of Malacca by the Dutch in 1641 led to the elimination of the Portuguese, and by that time the long rivalry between the Dutch and the English had already culminated in the practical withdrawal of the Portuguese from south-eastern Asia.

For a period the fact that both were Protestant nations, and that they were, in some sort, leagued together for the overthrow of the Catholic Portuguese, had made them attempt to work in unison. Differences, however, speedily arose. The principal bone of contention was the Spice Isiands, English claims to which were based upon Drake's visit to them during his voyage of circumnavigation, while the Dutch claimed monopolistic rights by virtue of conquest from the Portuguese, and on the ground of effective possession.

The Dutch, moreover, were strong advocates of expenditure upon forts and fleets and armaments, and complained that the English Company would not contribute its fair share of expenses incurred on these accounts. They had the advantage of constant and effective support from their Government, while even the massacre by them of the English factors at Amboyna failed to stir the anæmic James and the embarrassed Charles to any adequate action, and it was left to Cromwell to exact belated compensation from the States General a full generation after the event. That massacre and the loss of prestige which it entailed forced the English Company, little by little, to 
abandon its enterprises in the Malayan Archipelago, and this, in its turn, produced notable results upon both Dutch and British colonial policy.

The retirement of the English from the lands of south-eastern Asia left the Dutch in uncontrolled possession, and conferred upon them a freedom from restraint such as had formerly been enjoyed in even greater measure by the Portuguese. A century and a half of time had come and gone since the latter first set about the establishment of their monopoly of the sea-borne trade of Asia, and the civilisation of Europe had made during that period notable advances. The solidity of the Dutch national character, moreover, was to a great extent proof against the temptations to which their European forerunners had succumbed; but the weakness of the native kingdoms of the Malayan Archipelago enabled them with impunity to indulge in tyrannical and oppressive practices which if attempted in India would have led to the expulsion or to the extermination of the European merchants. To quote Signor Giordani's work, The German Colonial Empire:

The Dutch dedicated themselves more particularly to the great monopoly of spices, and in order that this might not escape from their hands, organised a mercantile government, suspicious, vigilant and exclusive, which did not admit foreign vessels into their ports, except under vexatious control and restrictions. They destroyed all the pepper, cinnamon, nutmeg and clove trees, the production of which exceeded the normal consumption, in order to maintain high prices. 
They addressed themselves, in fact, in a characteristically methodical and businesslike way, to the merciless exploitation of their colonial possessions, which from first to last have been regarded by them as sources whence the government of Holland should annually draw a substantial revenue. Law and order they have established; but their fiscal system, which is mainly borrowed from that of native governments, but is administered with European efficiency, not with the casual laxity that formerly rendered it bearable, imposes a cruel burden upon the people. Though the proselytising spirit, which made the rule of the Portuguese specially odious in Malayan lands, forms no part of the Dutch policy, scant sympathy is shown to the native population in other respects; and throughout the colonial possessions of Holland the Government systematically kecps everything in readiness for anticipated insurrection.

Since the end of the seventeenth century the Dutch system of colonial administration has undergone considerable improvements, but it is still distinguished by three special features. These are, firstly, that the colonies are primarily administered for the benefit of Dutchmen, secondly, that the revenues which they produce go to swell those of the mother country, instead of being exclusively used for the development of the land which provides them, and thirdly, that equality between white men and the natives is regarded as an inadmissible proposition. Limigration from the Dutch colonies is closely watched and carefully 
restricted; yet everywhere in British Malaya immigrants from these islands are to be found. Emigration from the British to the Dutch colonies, on the other hand, is unknown. That single fact is in itself, perhaps, a sufficient comment upon the virtues of the rival systems as judged from the standpoint of the natives.

The arrogant exercise of power to which their Malayan experiences had accustomed them, proved a bad training for the sort of work that awaited white men in India, where really powerful Native States were in existence. The Dutch, therefore, never achieved any important or permanent success in this newer and larger field of enterprise, upon which the English East India Company fell back, more or less in despair, after their failure to compete with Holland for the trade of the Spice Archipelago.

In India, so long as the Moghul Empire maintained its ascendancy, European merchants never dreamed of territorial expansion. They were completely at the mercy of the native rulers, and they had no means of exacting redress from them even when the treatment received was of the most humiliating or cruel description.

With the break up of the Moghul Empire, however, and as a consequence of the universal anarchy which marked its decline, an even more intolerable situation was created, and not only European commerce, but the very lives of the factors were for a space in the utmost jeopardy. A plain alternative presented itself. Either the white merchants must contrive to establish a reign of 
law and order, under which they, at any rate, would be secure from oppression, or they must abandon the enterprise to which they had clung, in spite of every conceivable discouragement and difficulty, ever since the collapse of the Portuguese monopoly of the sea-borne trade of Asia at the beginning of the seventeenth century.

The policy of utilising the rivalry of native princes to this end, and the expedient of training and disciplining native troops on the European model, which Macaulay mistakenly regarded as the invention of Dupleix, had been adopted by the Spaniards in America and by the Portuguese on the Coromandel Coast from very early in the sixteenth century. The Dutch, too, in Malaya, had made use of similar methods whenever the opportunity presented itself; and Dupleix's achievement in fact consisted merely in employing them in India upon a scale of unprecedented ambition and magnificence.

Clive was quick to appreciate their possibilities, and his genius made of them far more effective instruments than they had ever proved in the past. The object which he had in view, however, was not territorial expansion or the extension of British jurisdiction, as such things are to-day understood by Englishmen, for the East India Company which he served was engrossed by a single preoccupation-profitable, and if possible, peaceful commerce. When French intrigues and the rapidgrowth of French influence threatened the expulsion of its factors from India, it fought the French and the native princes whose policy 
the French inspired. When lawless native potentates persecuted or massacred its agents, it fought and defeated them; but enterprises of this description were shirked as long as possible, and when undertaken were entered upon with extreme reluctance. For the instrument which was at work in India, it must be remembered, was not the British Government, but instead was a commercial company, which entertained at this time no political or territorial ambitions, which regarded expensive campaigns and the extension of its responsibilities with marked disfavour, and which desired above all things to be suffered to carry on its legitimate business of money-getting in peace and quietude.

This, indeed, is the keynote of the policy of the English in India during the seventeenth century, if that can be called a policy which led to the acquisition of an empire, not of set design, but merely as a by-product, trade being throughout the real object aimed at. Even after Clive's extraordinary successes, the Company was perfectly content to be no more than the whisper behind the throne of the Nawab of Bengal ; was bent upon securing nothing save commercial advantages for itself; and was not in the least concerned to protect the native population from the oppression or from

1 the exactions of their rulers, provided only that the steady flow of its trade sustained no interruption therefrom.

The first step in this direction was taken by Warren Hastings. He, to quote the words of Professor Ramsay Muir, 
pensioned off the Nawab, took over direct responsibility for the government of Bengal, and organised a system of justice which, though far from perfect, established for the first time the Reign of Law in an Indian realm. . . . In the midst of the unceasing and desolating wars of India, the territory under direct British rule formed an island of secure peace and justice. That was Hastings' supreme contribution: it was the foundation upon which arose the fabric of the Indian Empire. . . His work was to make British rule mean security and justice in place of tyranny; and it was because it had come to mean this that it grew, after his time, with extraordinary rapidity.

Yet once again the motive which actuated this innovation was commercial security and advantage, not political ambition, far less any recognition of an obligation on the part of the English to ameliorate the condition of the native population.

None the less, Hastings, working more mightily than even he perceived, set up during his government of Bengal a wholly new ideal for white men serving and ruling in non-European lands. Until then they had been content to exploit the riches of the countries into which they had penetrated, and to concern themselves with their internal affairs only so far as European interests might be benefited or advanced by such intervention. Henceforth Englishmen, at any rate, were to regard the establishment of law and order, and the protection of the natives from tyranny and oppression, as essential parts of their duty. This was to impart to them a new sense of responsibility and obligation toward the native races with which, 
all over the world, it was fated that they should be brought into contact. It is this, more than any other single thing, which has led to the expansion of the colonial empire of Great Britain in tropical and subtropical lands.

In Hastings' day the idea that the establishment of European ascendancy in the non-European world should confer upon the native populations emancipation from tyranny and injustice-that it was part of the business of the white men to be the protectors and defenders of the people against wrong and oppression, not merely their pitiless exploiters-was an entirely novel conception. It had played no part in the conquests of Spain and Portugal. It had not entered into the calculations of the Dutch in their thorough and methodical exploitation of the Malayan Archipelago. It had found no place in the ambitious schemes of Dupleix. It was an invention of the English; and since, as we have seen, Sir Henry Campbell-Bannerman's aphorism strikes no answering chord in the hearts of the bulk of the peoples of non-European lands, the Reign of Law, which the British now inaugurated in India, and which has been the most notable of Great Britain's achievements throughout the tropical and subtropical world, acted as a magnet which, in these hitherto lawless regions, attracted to itself an ever-increasing multitude of mankind.

But Warren Hastings' administration is also memorable because it effected yet another revolution in the methods whereby the government of non-European populations had up to that time 
been conducted by white men; and this again was a characteristically English innovation. Isabella of Spain, it is true, had intervened to secure the repatriation of certain natives of South America whom one of her governors had transported to Europe; but the main preoccupations of the sovereigns of Spain and Portugal had been, not to afford protection to the native populations, but to exploit the wealth of the newly discovered lands, and to prevent their viceroys from assuming positions of too great power and independence. Their thought, in fact, had been for themselves and for their own revenues and authority, not for the hapless victims of their conquests.

The States-General of Holland had never had occasion to entertain similar suspicions or apprehensions concerning their governors; but they had given them a very free hand, and they had not been over-curious about their treatment of the natives, provided that their administrations were financially successful. It was left to the Commons of England to come forward as the champions of the native races of the non-European world, and to enquire with Brutus-like severity into the conduct of the very man who had laid the foundation-stones upon which British rule in India and in the tropics has since reared so mighty an edifice.

It was in 1773-eighteen years after the Battle of Plassy-that the British Parliament and Government first intervened and assumed a measure of responsibility for the affairs of the East India Company which, in one form or another, had been In existence ever since 1599. The Parliamentary 
proceedings taken against Clive, however, were not only inconclusive, but were also designed merely to check corruption on the part of the Company's servants; and they owed much of their venom to men whose own rapacity he had been instrumental in restraining.

The impeachment of Warren Hastings in 1788 occupies a wholly different plane of importance. $f t$ is as notable a landmark in the history of British territorial expansion as was the revolution in government of non-European lands by white men which the object of its attack had inaugurated in Bengal. That revolution substituted the Reign of Law for the Reign of Anarchy, and determined the principle that this for the future was to be the prime object. of and the sole justification for an extension of territory and jurisdiction in non-European countries. 'The impeachment established the no less important principle that unfettered power was never, in any circumstances, to be exerted in such countries by a British administrator, and that distance was to aiford to him no immunity from the control exercised by the laws of Lingland and by the public opinion of his countrymen.

We assert, [said Burke, speaking as the mouthpiece of the Commons of England, we assert that he is bound to use that power according to the established rules of political morality, of humanity, and equity. ... We aftirm, that in his relations to the people of India he was bound to act according to the largest and most generous construction of their laws, rights, usages, institutions and good customs 
The prosecutors took far too little account of the difficulties of the situations with which Hastings had been confronted. They ignored the constant pressure which had been put upon him by the directors of the Company in London to send home more money. They experienced the common inability to differentiate between the conditions that prevailed in India and those with which life in England had familiarised them; and they allowed their generous indignation to blind them to the greatness of Hastings' achievements, and to the immense services which he had rendered alike to Great Britain and to the people of Bengal.

Burke, moreover, who had so much to say on the subject of Indian codified law, failed to perceive that in lands where the executive is a law unto itself, no precept, written or oral, can restrain the excesses of arbitrary power. "An order is an order till you be strong enough to disobey it," says the Indian proverb; and all the native rulers of the kingdoms of Hindustan, who had enjoyed real authority, had invariably possessed the necessary strength whenever the law chanced to run counter to their convenience. In these circumstances, the existence of elaborate legal codes did not signify that their provisions were observed. Though the point escaped Burke, this was known to the population of Bengal by bitter experience, and Hastings had won their gratitude precisely because he had set up in their midst a system of law to which all men alike were required to bow.

The Lords acquitted Hastings, thereby adopting the course which most men are to-day agreed was 
the best, having regard to all the circumstances of an admittedly difficult case. His impeachment by the Commons of England none the less determined the principle once for all that the British colonial administrator was himself to be the obedient servant of the law.

This was a conception of the position of a ruler that was completely foreign to the ideas and to the experience of the native populations throughout the non-European world. It had never there been entertained by the government of any other European country in matters where its own interests were not in question, and where the well-being of a subject people was alone at stake. It was first conceived by British statesmen, and it has since been constantly reasserted and enforced. Even to this day, on the outskirts of some of those empires which the Powers of Europe have carved out for themselves, it differentiates British rule of backward populations from the jurisdiction that is exercised over them by the administrators of other nationalities.

The vindication of these principles of colonial administration in $\mathbf{1 7 8 8}$ was but the beginning of a long and painful climb from the depths of that dark valley in which repose, amid the bones of their victims, the earlier records of European tyrannies and oppressions in the non-European world.

But the first upward steps along that toilsome ascent were taken by Englishmen, impelled by no necessity save the dictates of conscience, a sense of moral responsibility and obligation, and above 
all by a characteristic love of fair play. In their colonial empires some European nations have followed in the footsteps of Great Britain, while some have lagged behind; but with the exception of the Americans, who, as late comers in the Philippines, were able to profit by a laboriously acquired experience, no European Power has climbed so high or has so nearly attained to the summit which our forefathers in the eighteenth century set themselves resolutely to scale. 


\section{V}

The impeachment of Warren Hastings was only one of many signs that the national conscience of Great Britain was surely, if slowly, awakening on the subject of our treatment of, and our obligations to, the native populations of the non-European world. In 1789-the year following that which witnessed the acquittal of Hastings-Wilberforce moved in the House of Commons his first resolution condemning the slave-trade.

This traffic had been inaugurated by the Portuguese during the closing years of the fifteenth century, but it was not long in assuming the character of an international enterprise of the first magnitude.

West Africa was, of course, the main source of supply. In the fringe of forest-country which in this region extends from the sea-board to a distance of some 200 miles into the interior, the tse-tse fly and the Trypanosomo, acting in unholy alliance, have dominated the land and have had a preponderating influence in the fashioning of its history. Trypanosomo of various species cause sleeping-sickness in human beings and breed a devastating murrain among cattle and horses. The population of the forest area has thus been deprived of the use of beasts of burden, an accident which has discouraged commerce in any save 
easily transportable articles; and as the jungles in which the tribes dwelt furnished each community with all necessaries, none of the principal incentives to peaceful intercourse and to cultural improvement have here been in operation.

To this is largely to be ascribed the primitive cultural condition of the natives when the West Coast of Africa was first visited by Europeans during the latter half of the fifteenth century. A certain trade in gold, in ivory and in slaves had been in existence for several hundreds of years with the Arabs. Muslim caravans crossed the Sahara or penetrated from the shores of the Indian Ocean to the western limits of the Sudan, and trade with them was carried on by the negroes of the West Coast of Africa at certain recognised depôts situated at the edge of the forest-country. Into the latter the Arabs rarely entered, for their way was barred by the tse-tse and the Trypanosoma which destroyed their horses and paralysed their mobility.

The arrival of the Portuguese, who presently had to compete with half the nations of Europe, effected no change in the character of the West African trade, but it diverted it from its ancient channels, and by stimulating it to an unprecedented degree, immensely increased its volume. A better and more easily accessible market was at once opened for gold and ivory, and as soon as European energy and enterprise were brought to bear upon the slave-trade, that traffic quickly assumed proportions unprecedented in history.

In the estimation of the Europeans of that 
period there was nothing repugnant to morality in this form of commerce. In the Roman Catholic world it had the express approval of the Papacy, while by the Protestant nations Biblical precedents could with ease be quoted in its justification; and in truth the notion that the inhabitants of the non-European world were to be recognised as possessing any of the rights claimed by Christians was a conception wholly foreign to contemporary ideas. Portugal, Spain, Holland, England, France, Sweden, Denmark and the Germans of Brandenburg all competed for the trade according to the measure of their several abilities; and the share which each secured was mainly determined by their relative maritime power, and later by the demand for slaves in the colonies of the New World which certain of these nations had acquired.

When in 1712 the Peace of Utrecht put an end to the long wars' in which Marlborough had taken so triumphant a part, Queen Anne announced to the assembled peers and commoners of England that, as part of the spoils of victory, "Spain would yield to us the fortress of Gibraltar, the whole island of Minorca, and the monopoly in the trade in negroes for thirty years."

This announcement aroused considerable popular enthusiasm, and nothing, perhaps, could more strikingly illustrate the attitude of the European mind toward this traffic at the beginning of the eighteenth century.

It would be tedious to attempt to trace in detail the growth and decay of the settlements in West Africa which were established by the various 
nations of Europe, beginning with the Portuguese in 1471, and ending with the Germans of Brandenburg, who obtained their forts on the Gold Coast and a portion of the island of St. Thomas in 1681 and 1685 respectively, and took a part in the slavetrade with the aid of vessels hired from the shipowners of Holland. As this, however, is the solitary colonial venture of Germany of any importance which bears an earlier date than the last quarter of the nineteenth century, it is necessary briefly to describe it.

Frederick William, the Great Elector, was heart and soul for colonial enterprise, but his people accorded to his projects a very tepid support. He first strove to form a Brandenburg Company of the East Indies, on the model of Holland and England, but in this attempt he failed somewhat ignominiously, and the rivalry of the Dutch caused his first effort to establish a German settlement on the Gold Coast also to miscarry.

Subsequently, however, forts were erected at two or three points in that locality, and the Brandenburgers also established themselves on the island of St. Thomas. For a space the newcomers took as active a part as they were able in the slave-trade; but though the spirit was willing, the flesh was weak. The German colonists developed no aptitude for their new task; they could not compete successfully with their European rivals; and by 1688, when Frederick William died, the debts of the Company already amounted to $£ 100,000$. Less than a quarter of a century later the portion of the island of St. Thomas 


\section{ENGLISH AND FRENCH IN AFRICA}

which the Brandenburgers had secured was surrendered without compensation to the Danish Company; the Germans had been evicted from the Gold Coast by the Dutch and the English; and the solitary colonial venture upon which the Hohenzollerns were to embark for a century and a half ended in humiliating failure and commercial bankruptcy.

The share which each of the European nations had secured by 1791 in the West African slavetrade may be conveniently illustrated by the following table :

\begin{tabular}{|c|c|c|c|c|c|}
\hline \multicolumn{4}{|c|}{ Nationality. } & Forts. & $\begin{array}{c}\text { Annual Export of } \\
\text { Slaves. }\end{array}$ \\
\hline $\begin{array}{l}\text { British } \\
\text { French } \\
\text { Dutch } \\
\text { Portuguese } \\
\text { Danish }\end{array}$ & $\begin{array}{l}\dot{\bullet} \\
\dot{\cdot} \\
\dot{\bullet}\end{array}$ & $\begin{array}{l}\bullet \\
\bullet \\
\text { • }\end{array}$ & $\begin{array}{l}\dot{\bullet} \\
\dot{\bullet} \\
\dot{\bullet}\end{array}$ & $\begin{array}{r}14 \\
3 \\
15 \\
4 \\
4\end{array}$ & $\begin{array}{r}30,000 \\
20,000 \\
4,000 \\
10,000 \\
2,000\end{array}$ \\
\hline Total & - & - & - & 40 & 74,000 \\
\hline
\end{tabular}

The Brandenburgers, as we have seen, had failed to "make good," and the Swedes had been eliminated by the Danes. Of the five nations still actively engaged in the traffic, the proportionate share of each had been determined by the considerations already mentioned, and the largest interest in the trade had therefore naturally been acquired by Great Britain and by France. France had at that time more extensive possessions in the West Indies than Great Britain, which had also recently suffered the loss of her American colonies. 
On the other hand, the British were gradually acquiring an ever-increasing preponderance in the carrying-trade of the world, and this was the factor which caused her stake in the slave-trade at the end of the eighteenth century to exceed that of her leading rival by fifty per centum, and to approximate to two-fifths of the whole traffic. Yet it was in England, whose material interests were thus involved to a far greater extent than was the case with any other nation, that the agitation for the abolition of the slave-trade had its beginning, and it was there that it was maintained, in the face of every obstacle, until the object aimed at was at last achieved. It is well to remember, moreover, that this act of sacrifice was made by Great Britain voluntarily, not in obedience to any external pressure or influence, but solely at the dictates of a strong moral impulse.

That which is sometimes rather slightingly alluded to as "the nonconformist conscience," has played a great and a noble part in English history. Its exponents, more especially when engaged in arraigning their country or accusing their countrymen, have not always been distinguished for the impartiality or for the soundness of their judgment. Indeed they have all too frequently appeared to start upon the assumption that England and Englishmen must be held to be guilty, or at any rate in the wrong, until they have proved themselves to be innocent and in the right-the which is a negation of the first principles upon which the criminal law of England is based. This has 
betrayed them into the commission of many mistakes and into the perpetration of some injustice, and it has laid them open to charges of prejudice, unfairness, and even lack of patriotism.

When all this has been admitted, however, the fact remains that the influence which they have exerted has been wholesome, for it has taught the nation to examine its conscience in the light of certain stern precepts of morality; and of late years it has been reinforced by the rationalists, who find in philosophic liberalism a no less unyielding code. The late Cecil Rhodes spoke of this school of English political thought as a manifestation of " unctuous righteousness" ; but it is, in a much truer sense, the product of the Englishman's innate love of fair play.

Its failures of judgment and of temper are almost invariably to be traced to the fact that it has believed itself to be championing the cause of the " under dog." When it has been harsh to its own countrymen it has been because it was convinced that they could take care of themselves, and that their alleged victims could not. When it has arraigned its country it has done so, not through lack of patriotism, but because it so loved England that it was jealous for her honour and fair fame, and would have her hold herseif, like Cæsar's wife, above suspicion. It has been a thorn in the flesh of many a British man of action; but who can doubt that it has helped to reform many abuses, to restrain many excesses, and that it has done much to purify England's rule in nonEuropean lands, and to make of it the least selfish 
and the most liberal system that any European nation has yet devised?

It was the "nonconformist conscience" in England that first became uneasy on the subject of the slave-trade. George Fox had denounced it as early as 1671 ; and the Society of Friends began the agitation in earnest in 1727. Five and forty years, however, were to elapse before a court of law was to rule that the landing of a slave in Great Britain forthwith conferred emancipation upon him ; and the first motion against the traffic was not moved in the House of Commons until 1776. Thereafter followed a struggle which lasted for thirty years, and in which, from $\mathbf{1 7 8 0}$ onward, all the religious denominations in England took an active part.

The agitation assumed the character of a veritable crusade. The abolitionists brushed aside all pleas and sophisms which sought to justify, or to palliate the iniquity of the traffic. They cared nothing for the material advantages which a preponderating share in the trade were supposed to confer. They were undaunted by the great political and social influences, and by the immense wealth that were arrayed against them. They endured with equanimity the contempt, the ridicule, and at last the hatred which they inspired. They were derided as faddists, condemned as revolutionary assailants of the sacred rights of property; they were buffeted, mocked and spat upon.

Theirs was an unpopular cause, and their only incentives for espousing it were a sense of duty 
and their conviction that their country was participating in the perpetration of a great crime. For a weary period they were voices crying in the wilderness, or rather in the heart of an angry crowd that howled them down; but they persisted stubbornly, and eventually on March 23rd, 1807, a Bill abolishing the traffic was passed through both Houses of Parliament.

To Denmark, however, belongs the credit of being the first European nation to forbid participation in the slave-trade to her nationals, a law to that effect being enacted in 1792 which came into operation in 1802. By the former date, however, Denmark's share in the traffic had dwindled until it had become smaller than that of any other country that was engaged in it, and her action did not therefore call for any very heroic sacrifice.

In France, where enthusiasm in the cause of humanity took the place of the religious motives whereby the English abolitionists were inspired, the Abbé Grégoire had succeeded in May 1791 in securing a vote from the National Assembly prohibiting the traffic in slaves. This was repealed in the following September, and it was left to Napoleon during the Hundred Days to decree the abolition of the trade. This, however, was not made effective until 1818, and its final enactment. was largely due to British influence, the measure having been urged strongly upon Louis XVIII during the negotiations which followed the banishment of Napoleon to Elba.

Meanwhile Sweden had followed suit in 1813, 
and Holland in 1814, and in the latter year Great Britain and the United States bound themselves by treaty to do all in their power to suppress the trade. In this work British sea-power was the principal instrument; and indeed it is not too much to say that the traffic could never have been put down had not England been, not only a consenting party, but the most active agent of its suppression. Not content with this, she bribed Spain in 1820 by a payment of $£ 400,000$, and Portugal in 1830 by an indemnity of $£ 300,000$, to come into line with other European Powers in this matter, thus expending more both of force and of money than any other nation upon the object which her people now had so near at heart.

A much more difficult matter was the question of emancipation, for though Adam Smith had condemned slavery on economic grounds, the belief was wide-spread that liberation would spell ruin for the West Indian colonies. The abolitionists never slackened in their efforts, however, and when once they had succeeded in convincing the British electorate that the action which they demanded was called for in the name of justice and fair play, their cause was won. Once again it was Great Britain - the country which, with the exception of the Southern States of the American Union, stood to lose most by emancipation-that was first in the field. The necessary Act of Parliament was passed in August 1838. France followed in 1848, Holland in 1863, and Portugal in 1878 ; while in the United States a great and 
terrible war had to be fought before the question could finally be decided in favour of emancipation.

Looking backward, one is disposed to wonder that anything so infamous as the traffic in slaves, and the hardly less iniquitous system of plantation slavery should have been tolerated so long. In those days, however, the hearts of men were not so tender nor were their sympathies so wide as they have since become. As late as .1819 some 190 crimes were punishable in England with death. Executions took place in public until 1868, and twenty years earlier were frequently witnessed both by men and women of apparent refinement. These things alone are sufficiently indicative of the comparative callousness of public feeling during the earlier part of the nineteenth century, and a consideration of what they imply makes it all the more wonderful that Great Britain, at immense financial sacrifice-emancipation alone cost her taxpayers $£ 20,000,000$-and under no external pressure, should have taken the action she did between 1808 and 1837.

Just as she had been the first of the European nations to realise and to recognise the rights of the native populations of the non-European world to equitable treatment and to claim due respect for their customs and susceptibilitiesjust as she had been the first to determine that, in the interests of those populations, her colonial administrators should be denied that arbitrary power which is so liable to abuse even in the hands of the wisest and most sympathetic-so now she resolved that no considerations of material 
gain or advantage, no dread of financial ruin, and no fear of the powerful interests she was assailing, should induce her to consent to the perpetuation of systems of which her national conscience disapproved. Had she willed otherwise, there was no force in existence that could have compelled her to take the course which she now voluntarily adopted. Her position as a great maritime Power was impregnable; without the aid of her Navy the trade could never have been effectually suppressed, and the general public opinion of Europe was by no means strongly in favour of suppression. Might was hers, and she was free to make of it what use she would. She elected to employ it in the cause of right-to use it, in fact, in the only manner wherein might can find its justification.

The national attitude of mind of which this was a manifestation has often proved difficult of comprehension to the statesmen of other nations, and has not infrequently been regarded by them as a mask which serves to cover a calculating hypocrisy. Napoleon when at St. Helena, as Lord Rosebery records,

could not understand, and posterity shares his bewilderment, why the British had derived so little benefit from their long struggle and their victory. He thinks they must have been stung by the reproach of being a nation of shopkeepers, and have wished to show their magnanimity. . . It was ridiculous, he said, to leave Batavia to the Dutch, and Bourbon and Pondicherry to the French. . . Your ministers, too, [he says,] "should have stipulated for a commercial mono- 
poly in the seas of India and China. You ought not to have allowed the French or any other nation to put their nose beyond the Cape. . . . At present the English can dictate to the world.

On this subject Professor Ramsay Muir writes :

The Cape was, in fact, the most important acquisition secured by Great Britain by that treaty [the treaty of, 1815]; and it is worth noting that while the other great Powers who had joined in the final overthrow of Napoleon helped themselves without hesitation to immense and valuable territories, Britain, which alone had maintained the struggle from beginning to end without flagging, actually paid $£ 2,000,000$ to Holland as a compensation for this thinly-peopled settlement. She retained it mainly because of its value as a callingstation on the way to India.

For, once again to quote Professor Ramsay Muir :

In 1818 Britain stood forth as the sovereign ruler of India. This was sixty years after the battle of Plassey had established British influence, though not British rule, in a single province of India; only a little over thirty years after Warren Hastings returned to England, leaving behind him an empire still almost limited to that single province. There is nothing in history that can be compared with the swiftness of this achievement, which is all the more remarkable when we remember that almost every step in the advance roas taken with extreme unwillingness. But the most impressive thing about this astounding fabric of power, which extended over an area equal to half of Europe and inhabited by perhaps one- 
sixth of the human race, was not the swiftness with which it was created, but the results which flowed from it. It had begun in corruption and oppression, but it had grown because it had come to stand for justice, order and peace. In 1818 it could already be claimed for the British rule in India that it had brought to the numerous and conflicting races, religions, and castes of that vast and ancient land, three boons of the highest value: political unity such as they had never known before; security from the hitherto unceasing ravages of internal turbulence and war; and above all, the supreme gift which the West had to offer to the East, the substitution of an unvarying Reign of Law for the capricious wills of innumerable and shifting despots.

Napoleon, characteristically enough, attributed the moderation of Great Britain after Waterloo to sheer stupidity, or alternatively to a dread of the adverse public opinion of the other European nations which might be excited were she to profit too greedily by her victory.

The real restraining influence, however, was public opinion in Great Britain itself, which in the mass has always been strongly averse from annexations. For more than a decade she had been carrying on a desperate campaign against the spirit of conquest of which Napoleon was the living embodiment. The combined sentiment of the nation was strongly opposed to any imitation of his methods. Who can doubt that if the conquest of India could only have been effected by the adoption of a deliberately aggressive policy, that course would have been at once rejected by 
the British Government and by Parliament ? As it was, British dominion grew throughout the non-European world, not of set design, but for the reasons which Professor Ramsay Muir so forcibly explains; and at a moment when, as Napoleon said, England could "dictate to the world," her statesman were content to purchase from Holland a colonial possession which the latter had lost as her punishment for allying herself with the tyrant of Europe. In so acting, they were unquestionably complying with the strong feeling of their countrymen that, in public no less than in private affairs, the rules of fair play, decency and equitable conduct should be observed.

That this should prove incomprehensible to Napoleon is not surprising. It has been and is a mental attitude which is no less unintelligible to modern Germany, and indeed to any Power which regards might as the only law, and coǹsiders that it imposes upon its possessors no corresponding obligations. 


\section{VI}

During the rest of the nineteenth century two further phases of the colonial expansion of Europe were destined to be witnessed. Of these the first, which lasted until 1878, was a period when colonies were in disfavour throughout Europe. Bismarck was a strong "no colonies" man. Even so sagacious and far-seeing a statesman as Disraeli spoke of them as " millstones about our necks" ; the Government of India complained that the Straits Settlements, which it then administered, were useless encumbrances; the Times in a leading article advocated the cession of Canada to the United States; and in 1865 a Select Committee of the House of Commons, reporting upon the British settlements in West Africa, strongly recommended gradual withdrawal from all of them, with the sole exception of Sierra Leone. This exception was made because Sierra Leone had been established as a place of residence for emancipated and rescued slaves-Zachary Macaulay was one of its earliest governors ; and it was not considered fair to abandon these people to the none too tender mercies of the natives of the interior.

The almost universal belief in the worthlessness of colonial possessions was, at this time, a very 
genuine sentiment, and nowhere did this conviction prevail more strongly than in Great Britain; yet in spite of this her over-seas empire steadily expanded. With the growth of Australia, New Zealand and the rest we are not here concerned; but in the tropics the twin policies of withdrawal and of non-extension of jurisdiction were over and over again determined upon and frustrated:

In West Africa, for instance, the raiding of the coast districts by the Ashantis forced upon the British Government the choice between protecting the Fanti and other tribesmen from nameless outrages, or abandoning them to their fate. The trade of the Gold Coast was then a much less valuable thing than it is to-day, but withdrawal would also have entailed its extinction. The Ashanti War of 1873-4 was accordingly undertaken, and thus within a few years after the Committee of the House of Commons had urged abandonment, Great Britain in this region found herself finally committed to the task of introducing law and order into the West African Hinterland.

Similarly, in the Straits Settlements the expansion of trade, and especially the development of the tin-mining industry by Chinese immigrants, presently produced a situation in the Malay States of the Peninsula, the indefinite continuation of which was clearly intolerable. Treaties were entered into with the Sultans of Pêrak and Sĕlangor and with the Chiefs of the Něgri Sĕmbîlan, with the sole object of securing a stable and moderately 
equitable system of government, such as is dear to the heart of Europeans and to the peace-loving Chinese, but found little favour with the Malayan rulers of those days. Here, as in so many other kindred instances, the object aimed at was the establishment of law and order in the interests primarily of trade, but also in no small degree because the miseries endured by the native populations excited genuine pity and indignation. For indeed the time was drawing near when the European sense of the fitness of things forbade toleration of tyranny and anarchy in countries in close proximity to the settlements which white men had established.

For the rest, toward the close of this period during which colonial possessions were in scant repute, the British Government took steps to make her tropical territories as compact as circumstances permitted, and was at pains to remove as far as possible any potential seeds of dissension with other European Powers that might lie hid in them. The most important of these measures was the treaty entered into with Holland in 1871, whereby Great Britain surrendered its ancient settlement at Bencoolen and withdrew all claims in the island of Sumatra, the Dutch waiving similar claims on the main land of the Malayan Peninsula, and ceding to Great Britain its remaining forts on the West Coast of Africa. Prior to this an attempt had been made by the two nations to exchange certain of their West African starions in order to make the sphere of influence of each geographically continuous. 
The natives of the areas which Great Britain proposed to cede so stoutly resisted the attempts of the.Dutch to establish their authority over them that the proposals had to be abandoned, and Holland finally withdrew from the Gold Coast, and received in consequence concessions in Sumatra which, at that time, were certainly of greater value than those which she had surrendered in Africa. The local results of this arrangement are instructive. The Ashantis promptly raided Elmina, the principal Dutch fort which Great Britain had acquired-an act which necessitated the short but not altogether decisive Ashanti War of 1873-4.

In Sumatra, on the other hand, the abandonment of Acheh, which had for many years enjoyed the nominal protection of Great Britain, led to a war of obstinate resistance to Dutch authority, which endured for more than a quarter of a century, and strained the financial resources of Holland's colonial possessions to near the breakingpoint. One incident connected with this struggle was the capture in $\mathbf{1 8 8 3}$ by the Achehnese of the crew of the shipwrecked British steamer Nisero, who were held as hostages for many months, the chiefs of Acheh declaring that they would not give them up unless and until the British protectorate over their country was restored. 


\section{VII}

"IN 1825," Professor Ramsay Muir writes of the colonial possessions of Great Britain, "this empire was the only extra European empire of importance still controlled by any of the historic imperial powers of Western Europe."

He should not have forgotten to include that of Holland, for apart from the fact that it to-day comprises an area of well over 800,000 square miles in extent, with a population of nearly $38,000,000$ souls, it has in another respect a peculiar importance. This attaches to it because the principles upon which it is governed are in abrupt contrast to those which Great Britain has adopted, and indeed, with slight modifications, approximate to those which this country had discarded before the end of the eighteenth century.

The policy of the British Government has been : firstly, to regard the revenues derived from nonEuropean possessions, not as perquisites of the Mother Country, but as funds which should be exclusively devoted to local services and to the development of the territories in which they are raised. Secondly, to demand no financial contribution from them on account of the Royal Navy with the upkeep of which their own existence is bound up; and to require payment for military 
purposes sufficient only roughly to cover the disbursements made by the Imperial Exchequer for their garrisons and fortifications. Thirdly, to . hold even the balance between the European settlers and the native population, ensuring the protection of the one, and preventing the unfair exploitation of the other, by retaining full control of the administration, but at the same time admitting representatives of both to a share in local counsels by appointing them to seats upon colonial Legislatures. Fourthly, to restrict customs duties to the requirements of revenue, to refrain from the imposition of preferential tariffs, and to throw British Crown Colonies and Protectorates open to the trade of all the world, without seeking to secure for British subjects any commercial advantages over their rivals of other nationalities. Fifthly, to insist upon complete equality before the law of all inhabitants of these possessions without distinction of race, nationality, creed or class. And finally, to respect, and as far as possible to refrain from interference with the religions, the customs, and the institutions of the native populations provided they are not repugnant to natural justice, equity or good conscience.

Of Dutch methods something has already been said. Here it is only necessary to insist upon the fact that Holland has always regarded her colonies as direct sources of revenue, and their maintenance and administration as matters which are primarily to be conducted in the interests, not of the native populations, but of Dutchmen. 
They, too, have abstained from interference with the religions and customs of their colonial subjects ; but they have looked upon native institutions mainly as convenient instruments for the extortion of labour and taxes, and they have never admitted, even in theory, any equality between Dutchmen and the coloured populations of their colonies. For the rest, to quote the words of the late Mr. Alleyne Ireland, "the keynote of Dutch policy is monopoly and exclusion." The incidents in Malaya and West Africa just recorded will serve to show which of the two systems-that of Great Britain or that of Holland-finds the more favour with the people of the non-European world. 


\section{VIII}

THE second phase of the colonial expansion of Europe which synchronised with the concluding quarter of the nineteenth century, was the period when the Great Powers of the civilised world of a sudden awoke to a new appreciation of the value of over-seas possessions, and with it to a desire for world-empire. Professor Ramsay Muir dates the beginning of this phase from the Berlin Conference of 1878, but it received its first impulse from the expansion of the French colonial empire, which in its turn was a direct result of the FrancoPrussian war of 1870. The defeat which France had sustained, and the loss of prestige by which it was accompanied, led to the carving out by her of empires of immense extent alike in Africa and in Indo-China, though in both localities she had secured, prior to that period, considerable commercial and territorial interests.

These projects were at first regarded by Bismarck with somewhat contemptuous approval, the more so since they threatened to complicate Anglo-French relations; for though France was only engaged in extending her possessions in south-eastern Asia, her sudden activity as suddenly translated questions of colonial expansion into the arena of European international politics. 
This inevitably imparted a new impulse to the territorial expansion of Great Britain in the East, since it kindled a desire to forestall inconvenient encroachments, and effectually to secure the land communications and the commerce of her existing possessions.

Thus the Burmese War of 1885 had for its object, not only the ending of the anarchical rule at Ava which so long had adversely affected commerce in British Burma, but also to seek a natural boundary with China in the gorges of the upper Mekong, a policy which was dictated by the rapidly-expanding French empire in Indo-China. The subsequent extension of the British protectorate over the eastern and northern States of the Malay Peninsula, with which Great Britain had not previously interfered, is also to be traced to the same source.

Professor Ramsay Muir, however, writes as follows, and the question of the exact date is of no material importance.

The Congress of Berlin in 1878 marks the close of the era of nationalist revolutions and wars in Europe. By the same date all the European States had found a more or less permanent solution of their constitutional problems. With equal definiteness this year may be said to mark a new era in the history of European imperialism; an era of eager competition for the control of the still unoccupied regions of the world, in which the concerns of the remotest countries suddenly became matters of supreme moment to all European Powers, and the peace of the world was 
endangered by questions arising in China or Siam, in Morocco or the Soudan or the islands of the Pacific.

For when the peoples of Western and Central Europe, no longer engrossed by the problems of Nationalism and Liberalism, cast their eyes over the world, lo! the scale of things seemed to have changed. Just as, in the fifteenth century, civilisation had suddenly passed from the stage of the city-state or the feudal principality to the stage of the great nation-state, so now, while the European peoples were still struggling to realise their nationhood, civilisation seemed to have stolen a march upon them, and to have advanced once more, this time to the stage of the worldstate. For to the east of the European nations , lay the vast Russian Empire, stretching from Central Europe across Asia to the Pacific; and in the west the great American Republic extended from ocean to ocean, across 3,000 miles of territory; and between these and around them spread the British Empire, sprawling over the whole face of the globe, on every sea and in every continent. In contrast with these giant empires, the nation-states of Europe felt themselves out of scale, just as the Italian cities in the sixteenth century must have felt themselves out of scale in comparison with the new nation-states of France and Spain. The indifference of Europe to the outer world, and her disbelief in the value of over-seas possessions, died out, and was replaced by an eager resolve to achieve the new standard of the world-state before it was too late.

It was then, and not till then-like labourers entering the vineyard viell after the eleventh hour had struck-that Germany leaped into the 
colonial arena. Her merchants and traders had taken full advantage of the openings afforded to them by the peaceful and prosperous conditions which had been established by the British throughout the colonial world and in places like the treaty ports of China, which they had been largely instrumental in rendering habitable for Europeans. In all the colonies of Great Britain and in the United States of America, whither a large portion of Germany's surplus population was perennially flowing, her subjects had enjoyed equality of opportunity and an open hospitality; and by virtue of their immense industry, their meticulous attention to detail, their intelligence and their methodical ways many of them had achieved marked success.

The task of colonial administration, however, was one to which their nation had never addressed itself. The few isolated attempts made by Germans to form settlements in South America and in West Africa on their own account had ended in ignominious failure. No previous training or experience, no inherited tradition, had fitted them for this novel form of enterprise; and indeed their highly-organised, machine-like and rigid system of government was of its very nature wholly unsuited for transplantation to, and was very difficult of adaptation to the purposes of what Mr. Kipling has described as "the raw and the naked lands" of the.non-European world. The colonial empires established by other European Powers-even those of Spain and Portugal which had owed so much to the keen personal 
interest taken in them by successive sovereignshad all received their main stimulus from a genuine, spontaneous national impulse.

Nothing of the sort was discernible in Germany. Though official propaganda was used to flog and galvanise public interest in a colonial policy into existence, it continued to be feeble and languid; and it was the German Government, mainly at the bidding of William II, that determined of a sudden to "hack" out a colonial empire for Germany, in spite of popular indifference, in order that the Fatherland might claim to rank as a world-state with Great Britain and Holland, with France, Russia and the United States of America.

The German Government was late in the field, and it was sadly and rather resentfully conscious of the fact. It came, not after the manner of the European Powers of the first five and seventy years of the nineteenth century, to preserve and extend existing interests in countries over-sea, and to establish order, good government and peace in lawless lands wherein it had a direct stake, but instead much in the same spirit of conquest and plunder whereby the early filibusters of the sixteenth and seventeenth centuries had been actuated., The immediate result was to precipitate a sudden "scramble" for territoryespecially in Africa, hitherto the-least exploited of the continents-an event "which, with the exception of the Great War into which the world has since been plunged through the same agency, is perhaps the least creditable incident in the 
recent history of the European nations. Some excuse may possibly be found for the other Powers which engaged in it, inasmuch as Germany's raid upon the colonial world compelled them in self-defence to establish satisfactory boundaries and to forestall her threatened encroachments; but here, as ever, the Government of William II brought not peace but a sword.

In Africa, for example, the definition of boundaries by meridians of longitude and parallels of latitude, though convenient to the European Powers, entailed the merciless severance of tribes which have as keen and close a sense of nationality as have the English or the French themselves. The wails of protest from the chiefs and people subjected to this treatment were recorded at the time in official documents, and make pitiful reading. In the worst days of the slave-trade no such collective injury had, in the estimation of these poor folk, been inflicted upon the tribesmen of Africa; and one does not envy the British officers who had to carry out the behests of the chancelleries of Europe, and to turn a deaf ear to the frantic prayers addressed to them. In many instances they were compelled to take away cherished Union Jacks by force from chiefs and people who were vehement in their determination not to receive the German flag in its place, and were indifferent to the anger they aroused in the German officers who were the witnesses of these demonstrations.

In the past, since early in the seventeenth century, the extension of European dominion in 
non-European lands had been a gradual and a natural growth. Jurisdiction over wider areas had, for the most part, been undertaken with extreme reluctance, and had been asserted in order to secure existing interests or to facilitate commerce by establishing law and order in troubled and troublesome territories adjacent to European settlements.

The colonial policy of Germany, on the other hand, had no such incentives of local expediency for its justification. She-came into the nonEuropean world "as a roaring lion walketh about, seeking whom he may devour." Her claims were based, not upon work which she had done in the past, not upon actual colonial interests which it was necessary that she should protect in the present, but solely upon her desire to become in the future a world-state like her neighbours. In a word she was bent upon plundering, and was in no wise concerned to justify her actions. She thus introduced into the practice of European territorial expansion a wholly immoral element, which was only not new because it was, in effect, a revival of the spirit in which the conquests of Spain and Portugal in the sixteenth century had been undertaken. In this connection Professor Ramsay Muir notes that there is

one fact which differentiates the settlement of Africa from that of any other region of the nonEuropean world : that it was not a gradual, but rather a very sudden and unprepared achievement; and that it was based in most cases not upon the claims established by work already done, 
but simply upon the assertion that extra-European empire was the due of the European peoples, merely because they werc civilised and powerful. Especially was this the case with the empire which Germany carved out for herself in Africa during the course of the next generation. In a degree unparalleled in the history of European imperialism, the German colonial empire was the result of force and of design, not of a gradual evolution. . . I It fell almost wholly within regions where, until its acquisition, Germany had been practically without any material interests. In every case British trade had previously been far more active than German in these regions; yet although the protectionist policy of Germany threatened to eradicate all rival interests, no serious difficulties were raised: the British Prime Minister publicly declared that if Germany wished to acquire colonies, her co-operation in the work of civilisation would be welcome.

Thus, in the space of little more than four years, was the colonial empire of Germany acquired. It remains for us to examine the principles upon which she elected to govern these colonies, the uses to which she put them, and most important of all, the fashion in which she "co-operated in the work of civilisation" in the dominions which she had so suddenly annexed. In what follows I shall confine myself to German colonial methods as practised inSouth-West Africa, in the Cameroons, in Togoland, and in East Africa, these being the territories which, for reasons already explained, it is most to be feared may incur the danger of being restored to Germany at the conclusion of hostilities. 
Germany, like the United States of America when the latter assumed charge of the Philippine Islands, being a late-comer in the colonial world, had at her command the laboriously accumulated experience of the other European nations which had preceded her in this field of activity and enterprise. She was free, therefore, to model her administration, and to frame her economic system in her newly acquired colonies, in accordance with any formulæ that had been worked out for themselves by other colonising peoples. In this sphere of human industry various schools of thought had arisen, of which, as we have seen, that of the British and that of the Dutch represented two opposed and strongly contrasted types. France had adopted a line of policy of her own-one which is less liberal, less accommodating, and much more paternal and interfering than that of the British, but far more generous and considerably less rigid than that of the Dutch.

Of the principles and methods of her colonial system it is not necessary here to make any examination; but those who are curious in such matters may be referred to the work of that very candid critic, M. Leopold de Saussure, Psychologie de la Colonisation Française dans ses Rapports avec les Sociétés Indigènes. It is interesting to noteand the fact is eloquently illustrative of the widely different national character of the two peoplesthat when the United States and Germany each had to make a choice of the models upon which its colonial policy was to be fashioned, the former selected the British, the latter the Dutch system 
for adaptation in the administration of its new possessions. On this point Signor Giordani writes :

The German colonial system, so young in years, ever remains the oldest system, because the most tyrannic, the most oppressive and illiberal, as opposed to the English-liberal par excellence. It represents the intensive exploitation of the colony to the detriment of the native population, and is nothing but a derivative of the rigid mercantile organisation created by the Dutch-and already supplanted by England-yesterday as to-day.

It would be grossly unjust to Holland, however, to suggest that the Germans, though they selected for their guidance the general principles of the Dutch colonial system, in preference to those which have found favour with the British, proved themselves to be wise, skilful or creditable pupils. The Dutch, no matter what the defects of their methods may be in the judgment of colonial administrators of other schools of thought and policy, undeniably possess a certain aptitude for the government of non-European populations. They may not make the natives contented, but they do make them diligent. They may not grant them any large measure of freedom, but they do secure to them a certain degree of prosperity. They rule their colonies primarily for the benefit of Holland and of Dutchmen, but incidentally they confer upon the people the inestimable blessings of peace. The Germans, by an oppressive and iniquitous system of forced labour, also succeeded in making their native subjects accept the curse 
of Adam; but for the rest, once more to quote Signor Giordani :

It is superfluous to-day, while we look on shuddering at the martyrdom of Belgium, to give particulars of the methods of colonisation practised by Germany in South Africa, in order to ascertain how the Germans, such capable directors of banks and conquerors of markets, are, owing to defects of race, unfitted for colonisation; colonisation, that is to say, considered as a work of education and the elevation of barbarous races. Whenever the Germans have a mission to fulfil, otherwise than one founded on a banking system, or some commercial stake, or on some barrack regulation, a mission of a moral nature that ought to prevail over brutal commercial advantage, they show themselves devoid of all elementary gift of intuition, of all capacity for adaptation and government; theirs alone the power to crush and to suppress. And to civilise even the country of the Hottentots, it is not enough to substitute for entire populations murdered, railways and machines; neither is it lawful, after so many years of colonial experience in Africa, to propose to treat with like measures the natives of Damaraland and the Arabs of the coast of East Africa.

I shall presently have occasion to show that the language here used is not exaggerated. For the moment, however, our immediate concern is with some of the fundamental principles upon which Germany based her administration of the native populations which a too complacent Europe had suffered to fall under her dominion.

As Professor Ramsay Muir has well said in a 
passage already quoted, "the supreme gift" which Europe has been able to offer to the peoples of the non-European world is "the substitution of a Reign of Law for the capricious wills of innumerable and shifting despots." It is precisely because Germany, as a matter of deliberate policy, denied this gift to the native inhabitants of her African colonies that her whole system of administration of them stands eternally condemned. In common with other European Powers operating in Africa, she was instrumental, after her own fashion, in suppressing inter-tribal warfare, and in stamping out certain barbarous practices, such as human sacrifice and the like.

On the other hand, the only criminal codes promulgated in these territories were made by express provision to apply exclusively to their European populations. As regards the natives, who of course formed the vast majority of her colonial subjects, no definition of offences was ever attempted, it being left to the judgment of each individual German official to decide for himself firstly, what in his opinion constituted an offence, and secondly, the nature and extent of its appropriate punishment. Thus the native populations in the German colonies, far from being relieved from the uncertain incidence of a tyrannical rule, were deliberately and formally handed over by the Colonial governments, with the sanction and approval of the Imperial Government in Berlin, "to the capricious wills of innumerable and shifting despots."

For the majority of Europeans, as any medical 
man of experience will bear testimony, residence in the hot climates of the tropics has at the best of times a somewhat fraying effect upon the nerves and temper. The mental condition which results causes many white men to become unduly "touchy" and hypersensitive-to make them suffer from the kind of unreasonable ill-humour which men in the eighteenth century were wont to call "spleen." In such a mood a man is quick to imagine affronts, to detect covert insult in quite innocent looks and gestures, to give way to anger on the slightest provocation, or on no provocation at all. To allow a man so situated a free hand to declare any act to be a crime at his sole discretion, and with it power to mete out any punishment that may seem to him to be appropriate, is an almost unthinkable piece of folly and wickedness; yet this is precisely the policy which the German Government deliberately adopted.

At the time of the outbreak of the Great War, Germany had had ample occasion to learn what an incentive, nay, what an invitation to commit, on the one hand excesses, and on the other constant petty acts of tyranny, this system offered to her colonial officials. None the less, the German Government and the majority of the representatives of the German people continued to approve it ; and even the late Herr Bebel and the Socialists in the Reichstag, while manfully protesting against the results of German colonial administration, failed apparently to realise that it was the system itself that was radically and criminally at fault. 
The only decrees of the Imperial Chancellor which relate to the jurisdiction to be exercised by German officials over the natives are in the nature of departmental instructions to the officials themselves. Of these the most recent, which are understood to mark a more advanced and liberal policy than those hitherto in vogue, bear date 1896. One of them, which was issued on February 17th of that year, provides :

In proceedings at law where natives are concerned, any measures for the purpose of obtaining confessions or declarations other than those allowed by the German Rules of Court are forbidden.

The infliction of unusual punishments, particularly in cases of suspected guilt, are likewise prohibited.

That the use of torture for the purposes named had, as a matter of fact, been pretty freely resorted to by German officials is, unfortunately, notorious, and here receives official confirmation; for the phrase " unusual punishments" must be read in conjunction with the following section which occurs in a Decree dated April 22nd, 1896.

The admissible punishments are :

Corporal chastisement (whipping, flogging), fines, imprisonment with hard labour, imprisonment in chains, death

A sentence of flogging is to be carried out with an instrument approved by the Governor, that of a sentence of whipping with a light cane or switch. 
A sentence of flogging or whipping may specify a single or double flogging or whipping.

The second case must not take place until after the expiry of two weeks.

An executive order by the Governors of the German colonies reads as follows :

The instrument of punishment sanctioned by the Governor is a rope's end about 60 centimetres long and 2 to $2 \frac{1}{2}$ centimetres thick. Only ropes' ends issued by the Government may be used. These must be softened by being beaten with a hammer or piece of wood before being used. When travelling floggings must be also carried out by means of the prescribed instrument.

No woman could lawffully be flogged, and a lad under sixteen years of age could only be whipped. Arabs and Indians, too, were exempted from flogging. These, however, were comparatively recent innovations. There were also other elaborate regulations relating to flogging, which, in theory at any rate, were calculated to prevent abuse.

There are, however, two salient points which it is necessary to note. The instructions contained in these decrees, while they require that a record of the punishments inflicted should be kept and forwarded every quarter to the Governor, are silent as to any form of trial being a necessary preliminary to punishment, and make no provision for evidence being taken and committed to writing. The second point is that flogging stands first on the list as the most ordinary of 
" admissible punishments." While, therefore, corporal chastisement was the usual manner of punishing a criminal offence, its infliction could be ordered by a German official on almost any pretext without any risk of intervention by a higher authority.

Thus in Lome it was a common practice for a German trader to inform the nearest Government officer that such-and-such a native had insulted him, and this sufficed, without any further enquiry or trial, to cause the individual named to be awarded five-and-twenty lashes. That number, as has been seen, was the legal maximum fixed by the Chancellor's Decree of 1896, but in the opinion of German officials it was inadequate, and it was only on rare occasions that any less number of strokes were awarded.

In British colonies, of course, corporal punishment is forbidden by law, except for a few specified offences, for example, rape, indecent assault, etc.; and so rigid are the rules in this matter that no flogging can be inflicted by a magistrate, even after a formal trial, until the sentence has been submitted to and approved by the Chief Justice. Similarly, a flogging may not be inflicted upon a recalcitrant convict in a colonial prison until the sentence has received the sanction of the Governor who, in his turn, is required to furnish to the Secretary of State for the Colonies a quarterly return, giving full particulars of the punishments of this character which he has authorised.

The German decrees are elaborate in their provisions concerning the delegation of powers of 
punishment by the Commissioners in charge of districts to their European subordinates; but the power to delegate was vested in them, and in practice almost every German official, from men of the rank of a non-commissioned officer upward, had authority to cause any native to be awarded twenty-five lashes whenever, in his opinion, he had deserved correction.

The "rope end" so meticulously described in the passage quoted above, was in practice a formidable whip fashioned from three interwoven strands of stout hempen rope. When Lome, the capital of Togoland, was captured by the British in the first week of August 1914, these whips were found forming an apparently essential part of the furniture of all bungalows inhabited by German officials, and of certain of their offices. In the stores of the local Public Works Department they were kept ready for issue in neatly trussed bundles of ten to the packet-fairly convincing evidence that a perennial supply was needed, and that the whips disappeared in use. It was not for nothing that the Germans, from one end of Africa to the other, were known to the natives by the nickname of "the twenty-fivers." 
Not content with making the native population subject to no fixed criminal law; with leaving the task of determining what acts, omissions, words or gestures constituted an offence to the whim of every individual German official with whom they might come in contact; and with empowering the former to inflict corporal punishment therefor at their discretion, the Colonial Government rigidly excluded the public from its law courts and caused all cases to be heard in camera, when formal trial was not altogether dispensed with. Legal process, however, was not regarded as in any way essential where a native subject of the Fatherland was concerned, not only in the case of trifling offences adjudicated upon by minor officials, but in much more serious circumstances.

Chief Dagadu of $\mathrm{Kpandu}$ in Togoland related the following facts to the present writer. They may be taken as a typical instance of German colonial procedure.

The Germans, he said, issued an order that the necks of men should be examined. (This, of course, was for the purpose of detecting the swollen glands which indicate the early stages of sleepingsickness, a disease which is endemic in this part 
of West Africa, but which attains to no alarming proportions as the bulk of the native population is immune.) Men who were found to have enlarged glands were removed from their homes, and taken to a camp which the Germans had established on a neighbouring hill at a place called Kluto. Shortly after their removal, said Chief Dagadu, these men died. He obviously attributed their demise to their segregation at Kluto, though it was probably due to the disease from which they were suffering, no very effective remedy for it having at that time been found.

No effort appears to have been made to explain to the natives, or even to their chief, the scientific and philanthropical objects which the Germans had in view. It is not in accordance with German ideas of dignity to condescend to such a course, though it is probable that no explanation that a white man could offer would convince an African of a bush district that imprisonment for life, usually attended by premature death, was a just punishment to inflict upon a man for the crime of having a swelling in his neck.

Dagadu went to Misahöhe, the capital of his district, and later to Lome itself, where he had an interview with the Governor, Herr Brükner, and humbly begged that his people might be suffered to live and die in their own homes, no matter what the condition of their glands. The request was refused, and Dagadu returned to his home at Kpandu. The only message of comfort which he brought back to his people was that the Germans were about to experiment with a new 
drug which they had reason to think would prove more efficient than that hitherto employed by them.

Not long afterwards the present writer paid a visit to Togoland, and in the course of it spent a few hours at Kpandu. A week or two later Dr. Grünner, the Commissioner in charge of the Misahöhe district, arrested Dagadu. He was detained for two months in the prison at Misahöhe without charge made, and without trial. He subsequently learned that he was accused of having written two letters, one to the German Minister for the Colonies, and one to me, arraigning German rule in Togoland. Neither of these letters was ever produced then or later; Dagadu has consistently asserted that he never wrote any letters of the kind; and the one which is alleged to have been addressed to me certainly never reached its destination. None the less, still without trial or even being called upon formally to plead, Dagadu was taken to Lome, and was thence shipped to Duala in the Cameroons, where he was lodged in an association-ward in the common gaol. His son, his nephew and one of his wives, who had followed him to Duala, were allowed to see him once a month.

He remained in the prison at Duala some nine months; but upon a certain day shells from a British cruiser began to fall thick and fast among the public buildings of the German capital, and its defenders determined to beat a retreat. Two days later the German gaoler entered Dagadu's cell in tears, wrung him by the hand and, leaving 
the doors open, took his departure sobbing bitterly.

Dagadu made his way to the quarter of the town in which his wife was living with her companions; and as soon as the British and French troops had landed, he put himself in communication with the English general, and was by him shipped back to Togoland. His arrival at the railway station at Misahöhe, whither all his tribe had assembled to greet him, was a dramatic and moving spectacle; and the old man, almost smothered by his people, who swarmed about him like bees about their queen, was carried over the hills in triumph to Kpandu. 


\section{$\mathbf{X}$}

From the foregoing it will be seen that the German system of rule in their colonies, even where it can claim to have established a state of order, has not so much as contemplated the introduction of a system of law; that it accords to the native no rights of person; that it renders him liable to punishment without any legal process ; that he is not even permitted to know what acts constitute offences; and that power of corporal punishment is placed in the hands of subordinate officials upon whom no close check is kept, while the colonial Government itself does not hesitate to deport its subjects without trial. Such a system, it will be realised, would inevitably lead to abuses even if the men who administered it were the kindest and most merciful members of the human family. The men in question, however, were-Germans. The world knows by the experience of the past four years something of what that one word implies, even in localities where the public opinion of the civilised nations must be supposed to have acted, in some small degree, as a restraining influence.

But in the African colonies the only public opinion in active operation was itself German. The natives were always regarded as a "con- 
quered people," and to-day the meaning which that term bears in German parlance is also sufficiently notorious. Where pity, chivalry and decency failed, as they failed in Belgium, to restrain Germans from the commission of the worst excesses, how think you did it fare in the seclusion of the African bush with defenceless negroes and negresses, who were not even white folk like the more recent victims of German cruelty, brutality and lust?

These pages are concerned with the German system of colonial administration, rather than with the abuses and tyrannies which it was so nicely calculated to facilitate. It is none the less necessary to mention that the freedom of their womenkind from molestation by white men is a matter of the first importance to native populations. Feeling on the subject runs very high; and though in West Africa, for instance, succession is traced through the mother, native law expressly excludes a white man's bastard from the enjoyment of certain tribal privileges. This in itself will suffice to show the disfavour with which unions between white men and native women are regarded.

In the German colonies, however, the highest officials, not excluding governors, chief justices and the like, saw nothing shameful in the almost open practice of concubinage; and an example such as this could not but be productive of a very low standard of morality among their subordinates. When to this we add the fact that German officials had the power to punish any who chanced to 
offend them, and it will be realised how completely, in this important matter of the protection of their women, the natives were placed at the mercy of their white masters.

On October 18th, 1913, Grand Duke Adolf Friedrich of Mecklenburg, who at that time was Governor of Togoland, issued a law forbidding natives to assume or make use of German patronymics. The reasons which rendered the promulgation of this measure locally desirable were sufficiently scandalous and notorious; but it was not possible by this, or by any similar means, to preserve the "good name" of highly placed Germans in the African colonies. That was something which by their own misconduct they had irretrievably lost. 


\section{XI}

THese were not the only respects in which the German conception of the fashion in which the task of " co-operating in the work of civilisation" should be performed entailed serious encroachments upon the liberties and rights of the natives in their abruptly acquired African colonies.

Throughout the tropical world the labour question is one of perennial difficulty, though it is, of course, more acute in some regions than it is in others. It differs from labour questions in the civilised world because in the tropics, speaking broadly, there is no permanent artisan class, the average native being, on the contrary, a small landed proprietor, even though he may on occasion, in order to meet his personal convenience, be ready to work for a wage. He is not by nature venturesome, and so long as things go well. with him in his native village, and provided the produce of his land can supply him with the food, raiment and other necessaries which represent the modest requirements of himself and those immediately connected with him, he has scant inclination to quit his home or to embark in any unusual form of labour at a distance from it. In these hot climates, however, the cultivator is more completely dependent for his prosperity 
upon a sufficient and regular rainfall than are agriculturists in other parts of the world; and the occurrence of a drought may at any moment reduce him and his to very considerable straits. On such occasions the young and able-bodied members of the rural communities throughout a wide area may be compelled to seek work at a distance in order to relieve the necessities of the rest, and during bad seasons neighbouring labourmarkets will be glutted, while in good ones they are liable to be proportionately depleted.

The European-owned tea-estates of Ceylon, for instance, are worked by a labour force of Tamils which numbers half a million or more. The men and women who compose it are voluntary immigrants from the less fertile regions of the Madras Presidency, and while in Ceylon they regularly remit money to their relatives in India, and eventually return to their homes when they have amassed the funds they require. By watching the readings of the rain-gauges of Southern India, it is possible to forecast with considerable accuracy the volume of this stream of migration to and from Ceylon in any given year, so completely is the latter regulated by the former. Ceylon itself carries a population of over $4,000,000$ souls, yet very few Sinhalese can be induced to work upon the estates. They live in a country where the rainfall is both regular and abundant, and they very naturally prefer the cultivation of their own land to work done for a wage on the property of other people.

The average native of tropical Africa is very 
similarly situated. A certain area of land, enclosed within loosely defined boundaries which are often the subject of acute disagreement, is recognised as the exclusive property of a given tribe; and though portions of it may belong in a special fashion to particular sections of the tribe or to certain clans and family groups, the possession of this land, as the collective property of the community, is the foundation upon which the whole tribal system of the Africans is ordinarily based. The tribesmen have always been accustomed to keep in repair, by means of communal labour, the trade-routes which pass through their territory; but for the rest they have been free to work on their own account, and as much or as little as seemed good to them. Each individual has been at liberty to claim his share of the tribal lands for the cultivation of his food-plots, to exploit the produce of the tribal forests, and to build his hut from the material yielded from them.

A ready market for the oil and kernels obtained by him from the self-sown palm-trees has been furnished by European traders, and thus in the fringe of forest-country along the coast his principal requirements have without difficulty been satisfied. He accordingly has no inducement to sever his connection with all his friends and relations, and to seek employment at a distance from his home, the more so since the work of cultivation and of exploiting jungle produce, as he understands these things, is of a very unexacting type.

In the coast towns a class of artisans is coming 
into existence, but the main labour forces throughout tropical Africa are recruited from the comparatively barren interior whence pressure of circumstance, such as periodically operates in Southern India, from time to time compels emigration. The labour markets of tropical Africa, however, are never overstocked, and the work of development upon which Europeans are here engaged demands an ever-increasing supply of able-bodied toilers. Railways cannot be constructed, metalled roads cannot be made, buildings erected or mines worked unless the necessary labour is available; and when the voluntary co-operation of the natives cannot be enlisted to furnish this requirement, the temptation to resort to compulsion is apt to be strong.

The African whose country is being developed, it is argued, if he will not spontaneously assist in the work, should be compelled to do so; but this is not a point of view that commends itself to the natives. Taken in bulk, they have no great desire to see the work of development pushed forward upon European lines, though they are quick enough to profit by the new facilities afforded to them. Their preoccupation is to supply their actual wants at the cost of a minimum of toil ; to lead the life to which they are accustomed with as little extraneous interference as possible; and to confine their public industry to such forms of communal labour as have the sanction of their tribal customs. To compel them to toil on public works, or in mines 'or on plantations, is to upset the entire scheme of their existence. 
In the British colonies of tropical Africa this is recognised, and nothing in the nature of compulsion is attempted; yet for the most part they suffer from shortage of labour less acutely than do corresponding areas under the rule of other European nations. This is due to the fact that it is notorious among the native populations that a "stranger" is more free to come and go in British territory than anywhere else. In a British colony he will not become liable to pay heavy direct taxes, will not have to suffer the harassing attentions of too inquisitive officials, will not find himself immeshed in a maze of incomprehensible regulations, will not be constantly getting into trouble without clearly knowing why, and will be at liberty to work or loaf according to how the spirit moves him. If, therefore, circumstances compel him to seek work at a distance from his home, he very usually selects a British colony as the scene of his activities. Family affections and interests and tribal ties are all strong in him, and sooner or later, if all goes well, he hopes to return to his own people. In the meantime, however, the British colonial labour markets are the richer by his presence.

The Germans in their African possessions speedily found themselves " up against" the labour question, and having regard to the standpoint from which they regarded native questions, they forth$\checkmark$ with resorted to compulsion. Now the African of the tropical bush areas is accustomed, as has been said, to keep open the trade-routes through the country belonging to his tribe by a system of 
communal labour. To transport such labour to a distance, however, and to compel it to build roads on the European model through territory claimed by some other tribe was a monstrous iniquity, judged from the native point of view. It not only entailed exile from their homes, the suspension of the cultivation of their land and other private affairs necessary for the support of their dependents, but it placed them, in their opinion, in a servile position vis-d-vis the tribesmen of the district whose development was being effected by their labour. Yet this was the system to which, in Togoland for instance, the Germans had recourse upon a large scale, and the results are peculiarly instructive.

To begin with, the wide-spread discontent which was aroused had a very stimulating effect upon emigration, and Togoland natives streamed into the neighbouring British colony of the Gold Coast precisely as water runs down' hill. The disturbance occasioned in the pursuit by the natives of their ordinary avocations became more and more acute as the able-bodied portion of the population annually decreased in numbers. To avoid the corvée and other ills to which the proximity of German officials subjected the people, small family groups removed to distant spots and there cultivated their land; but as head-carriage was the only means of transport whereby their produce could be conveyed to market, and as this work had to be performed by the cultivators themselves, the remoteness of their farms caused a great deal of time and labour to be wasted on 
carrying, with the result that the volume of their annual crops was greatly reduced.

As a net result, at the time of the British occupation of Togoland, the Germans had a fine system of roads, which in their day had been much admired by Mrs. Gaunt and other superficial and casual observers; but the only vehicles that passed over them were two motor-cars belonging to the Government, and a few handcarts the property of the local Public Works Department. They had a thoroughly disgruntled and resentful native population, cultivating its crops in out-of-the-way holes and corners, and carrying the dwindling bulk of its produce on their heads to market along those roads; and though the latter were pleasing to the eye, they had retarded, not advanced, the development of the colony.

At the end of two years after the capture of Lome, the natives having in the meantime been relieved of forced labour in distant districts, and freed from their terror of the white men, 33 per cent. more land was under cultivation in the British sphere than at any period under German rule, and most of the farms were newly opened areas situated in close proximity to the railways and highways. Meanwhile, such was the prosperity which had resulted from half a century of more liberal rule across the border in the Gold Coast, that, in the same year, a neighbouring tribe acting on its own initiative was paying an Italian contractor $£ 8,000$ to build a motor-road for its members, leading from their cocoa-gardens in 
the plains to their towns on the summit of the Akwapim range, the object of which was to enable the cultivators to spend their week-ends in the bosoms of their families.

A great deal has been said and written in praise of the superior " efficiency" of German methods even in the colonies of the Fatherland, but though we be content to eliminate all higher standards of comparison, and to judge them purely by gross material results-the meanest of all criteriathey must even then be admitted to have proved a deplorable failure. The machine-made system of colonial administration which the Germans instituted was based upon a cold academical calculation concerning what course was most likely to conduce to the advantage of Germans. Theoretically it may have been sound enough; but in practice no system of administration which is the product of the brain alone, untempered by any of the principles of a higher morality, untouched by human sympathy, and inspired throughout by a brutal selfishness, can bring anything save misery to those to whose affairs it is applied, and disappointment to the men who invent and apply it. 


\section{XII}

As has been noted, the whole tribal structure of the native communities of Africa is based upon the exclusive ownership of their land. Any interference with it, therefore, strikes at the root of native institutions and is violently resented by every tribe and by every individual composing it. The natives are aware that, in the past, no tribe has ever lost any of its territory save as the direct result of a defeat inflicted upon it in battle. Expropriation, therefore, is felt by the natives of Africa to be as much a moral as a material injury.

- The loss of their tribal property is keenly resented, for it curtails the rights of user which each individual in the community has regarded as the exclusive privilege of himself and his fellow tribesmen; but a still more passionate sense of grievance is caused by the fact that the material loss places the tribe, in the opinion of its members,

- in the humiliating position of a despoiled and conquered people.

The Germans took no account of such sentiments. They desired to secure large areas for conversion by German speculators into cultivated estates, and the British system of allowing the native tribal authorities to make their own bargain with the would-be concessionaires, subject only 
to its revision in the interests of the former by a Concessions Court, did not appeal to them. Accordingly the colonial Government stepped in and expropriated the land desired by German planters. In many instances, it paid compensation to the tribes concerned upon a scale determined by itself; but this did not meet the objections of the natives, whose resentment was caused by the fact that the land was being taken away from them whether they objected or consented.

In Togoland, where tribes were compelled to accept compensation in spite of all their protests, the money paid over to them was regarded by them as tainted, and no man would have aught to do with it. At the time of the British occupation the coins were often produced, apparently precisely as they had been received, the chiefs and people begging to be relieved of the custody of money, the possession of which was regarded as a humiliation.

To obtain labour to work on plantations which had thus been brought into being was, of course, impossible unless compulsion were resorted to; for no native would willingly do a hand-stroke upon estates, the very existence of which was looked upon as a standing insult and offence to the tribes which had been dispossessed. Accordingly, the German colonial Government found it necessary to compel the natives to help open up and cultivate these plantations, though the forced labour was now exacted, not for public purposes, but for the benefit of private companies and individuals. A fair, though by no means 
extravagant, rate of wage was paid to the labourers ; but, as they were given the alternative of working on these properties or of being flogged until they consented to do so, the distinction, between the system so established and ordinary slavery must be admitted to be a fine one. 


\section{XIII}

IN the foregoing examination of the German colonial administrative system the concrete examples quoted have, as far as possible, been taken exclusively from the records in Togoland. This course has been followed of set purpose, because Togoland was at once the most peaceful and the most prosperous of the German colonies in Africa ; and because, with the exception of a massacre of Konkomba tribesmen at Yendi in northern Togoland - the men and women of the tribe, on that occasion, being lured to the administrative headquarters of their district by friendly representations, and then treacherously surrounded and shot down-Germany's peculiar fashion of " co-operating in the work of civilisation" was here less pronouncedly outrageous than it was elsewhere. Thus in Togoland it is possible to watch the German system of colonial administration working at its best and amid the most favourable circumstances.

It will have been noted that both in the matter of labour and of land, the Germans persistently ignored the native point of view, and paid no heed to the sanctity which attaches, in the estimation 
of a primitive people, to their immemorial customs and to the traditional sentiments connected with them. When, in 1788, Burke laid it down that in our relations with the people of India we were " bound to act according to the largest and most generous construction of their laws, rights, usages, institutions and good customs," he enunciated a principle which experience has shown to be as vitally important from the standpoint of policy and expediency, as it is from that of morality itself. It is because this principle was not so much as dreamed of in the German philosophy of colonial administration that the attempts of the Fatherland to govern peoples of the nonEuropean world and to develop their countries has been, not only a failure, but a monstrous tragedy.

The worst and most notorious example of the inability of the Germans to understand native sentiment and ideas, to realise their importance, and to grasp the necessity of sympathising with and deferring to them, is supplied by the pitiful story of the Herrero and Damara Hottentots of South-West Africa.

At the time of the German occupation of this territory - an act of acquisition which admittedly had for its justification the slenderest foundation of existing German interests in this region-the native population was estimated to number between 750,000 and $1,000,000$ souls. To-day it has dwindled to about 200,000-in itself a sufficiently blistering comment upon German colonial methods. The cause of the war of extermina- 
tion, of which this depopulation is the result, should be examined with some care.

The area of the German colony in South-West Africa was some 384,000 square miles-about half as large again as that of Germany itself ; but the greater portion of it is sour, arid, waterless country, though in certain localities tracts are met with which are suitable for pasturage. The natives of the more favoured regions were a pastoral people, whose worldly possessions were their land and their cattle. Without their land, over which their herds perpetually roamed at large, the cattle could not be maintained, and the entire foundation upon which their communal life was based would be undermined.

The German colonial Government, however, could not suffer such large areas of comparative fertility to be monopolised in this prodigal fashion, and a policy of expropriation was accordingly resolved upon. This met with resistance naturally enough, but the opposition offered to the European invaders was not of so stubborn a character that it could not be overcome. It was not until the Germans began to lay violent hands upon the herds of the Herreros and Damaras that every man's hand was forthwith turned against them; for here a deeply ingrained religious sentiment of the people came into play.

Though these tribesmen had long been accustomed to sell their surplus cattle over the border in Cape Colony, and though they were now ready similarly to dispose of them to their new masters, certain of their herds were regarded by them as 
being in some peculiar manner the property of their gods, and these it was sacrilege to part with in any circumstances. Such fine distinctions did not have any, weight with the Germans, and accordingly when the cattle belonging to the people had dwindled in numbers, partly owing to the restricted areas now available for pasturage, and only the sacred herds were usually available wherewith to satisfy debts due to German traders, the colonial Government did not hesitate to sequestrate them.

This meant war which, from the German point of view, was not altogether undesirable. The Hottentots were poor material from which to recruit labour forces; the sight of them and their live-stock sprawling over the only fertile districts in the territory was a constant offence to economical German eyes; as cultivators of the soil they were beneath contempt, and were judged to be incapable of sustained effort. They were to be accounted, therefore, mere useless cumberers of the earth, and their systematic extirpation was determined upon in the holy name of Kultur.

The policy embarked upon was carried out with characteristic German thoroughness ; yet even so it was a task that occupied several years. The Hottentots, fighting for their gods as well as for all their poor worldly possessions, turned upon their oppressors with the desperate ferocity of trapped and tortured animals. Appalling things were done by them to any Germans who had the ill fortune to fall into their hands ; but the outrages perpetrated by these hapless savages never 
attained to the magnificence or to the ruthlessness of the German counter-effort. No quarter was given. The natives, men, women and children, were driven in thousands into the waterless desert, and even then were followed up and slaughtered with every circumstance of atrocity as they lay dying of thirst. The story has been often told, and revolting details cannot add to the hideousness of the facts.

It is well to remember, however, that in Damaraland the exterminators of the Hottentots were men of the race whose doings in Belgium stand recorded in the awful pages of the Bryce Report; that here they were not dealing with men and women and children of European blood, whose kinship to their conquerors might be supposed to awake some feeble impulse toward compassion, but with defenceless negroes, whose pleas for mercy were unintelligible, and whose extermination had been undertaken as an act of deliberate policy. If unspeakable horrors and cruelties were perpetrated in Belgium in the full sight of an outraged civilisation, is it to be wondered at if the doings of the Germans in the seclusion of South-West Africa, when divorced utterly from all restraining influences and from all fear of eventual retaliation, beggared the worst of the enormities committed by the Spaniards and the Portuguese in the early years of the sixteenth century?

It is also worth noting that while these things were going forward without any effective protest being raised in Europe, the agitation anent the 
Belgian atrocities in the Congo was being stagemanaged by those distinguished patriots, the late Sir Roger Casement and Mr. E. D. Morel; and Germany, with an eye to possible territorial expansion in Africa, was joining in the hue and cry. 


\section{XIV}

THE war with the Hottentot tribes of Damaraland is the most notorious of the various campaigns upon which Germany embarked as soon as her "spheres of influence" had received concrete form through the instrumentality of international agreements; but the spirit of frank brigandage, by which her sudden entry into the colonial world had been inspired, continued to fashion her policy in the lands which her diplomacy had won. These territories had been surrendered to her demand by the other colonising nations of Europe, and though the mere assertion of her claims had sufficed to make them hers, she was perhaps justified in regarding them as the captives of her bow and spear. This, at any rate, was the aspect which they wore in her eyes, for she entered them, not in the rôle of a liberator, but in that of a conqueror. She had made good her claim to them as against the rest of the civilised world by virtue of her " mailed fist" and her "shining armour" ; it remained for her to win them from their indigenous inhabitants by a more forcible application of the policy of "blood and iron."

Taken in bulk, the natives of Africa are among the most prosaically utilitarian of mankind. Even when sentiment carries them away, it will 
usually be found that adherence to it has, in their judgment, a more or less close connection with material considerations. Thus, when the Herreros fought and died to resist the laying of sacrilegious hands upon their sacred cattle, they were probably inspired by the belief that the calamities which would result from the wrath of their outraged gods were more to be dreaded than any horrors that human beings could inflict; for subconsciously the African appears to be for ever keeping a running account with life.

For instance, he has a hearty and inherited dislike of work, which is the more easily comprehensible when it is remembered that in the tropics over-exertion frequently precipitates an attack of malarial fever-the onslaught of an enemy which is for ever lurking watchful in his blood. He can be induced to overcome this aversion when he stands in need of a regular income; but if you increase his wage with the object of attracting more labour, he is apt proportionately to reduce his hours of toil, since he can now secure the money he wants at a smaller sacrifice of comfort and convenience. Similarly, though he is conservative by nature, he will accept innovations willingly enough provided he is convinced that the balance of advantage warrants such surrender of sentiment. He requires, however, to be fully persuaded that real and tangible benefits will accrue to him as a result of his decision; and as he is at once suspicious and cautious, he is not prepared to take anything on trust.

Such a people are not very difficult to lead, 
provided they be patiently and sympathetically treated; but, on the other hand, they are well nigh impossible to drive. The Germans regarded the latter course as the only policy that their dignity rendered appropriate. They were not content to allow their influence and jurisdiction gradually to extend by a process of natural growth. They did not attempt to convince the African that material advantages were to be secured by the acceptance of their rule; but they were bent upon showing him that condign punishment would be the lot of any who hesitated to accept it.

This, of course, was the surest way to excite passionate and practically universal opposition; and indeed a more intimate acquaintance with the German system of colonial administration speedily convinced the natives that they had, in fact, nothing to gain, and a great deal to lose by submitting themselves to it. They found that the advent of these strangers, while seriously interfering with many of their most cherished customs and traditions, gave them nothing in exchange save harder conditions of life, more severe taxation, longer hours of labour, more frequent punishments, and less personal freedom. Even when, as in the case of the attempted campaign against sleepingsickness in Togoland, the Germans were inspired by the most laudable motives, they were so scornful of native opinion, and so ignorant of the art of dealing with a primitive people, that their most humane efforts were made to wear the guise of cruelty and oppression.

But above and beyond all this, German rule 
did not everi cónfer tón the people of her colonies the easily recognisable blessings of an evenhanded justice; and far from bringing peace, it plunged district after district into war-not the comparatively mild intertribal warfare to which the natives were more or less accustomed, but protracted struggles with an enemy no less savage and ruthless than themselves, who was armed with weapons of destruction of a diabolical efficiency and precision.

War, then, German war, waged with the brutality and the cynical cruelty of which Germans have proved themselves even in Europe to be such past-masters, was the first and principal gift which the Fatherland conferred upon her African subjects in the name of progress and civilisation. We have already glanced at the war of extermination in South-West Africa; but in her East African colony and in the Cameroons, Germany was no less successful in antagonising the whole native population. Africans have shown themselves very generally ready, when a fight is over, to shake hands and to make friends to-day with their opponents of yesterday. They are not naturally or by temperament good haters; but they are possessed of much robust self-respect, and, even after defeat, they will not contentedly accept the position of a conquered people.

This, however, is the standing which German policy has assigned to the native populations of her colonies from the beginning, and accordingly the extension of her jurisdiction has always met with resistance, and never for a moment has her 
rule stood "broad based upon a people's will." Alike in East Africa and in the Cameroons, her colonial record is one of armed conquest, followed by frequent " revolts." Knowing what we know to-day of German methods of making war, it is unnecessary to fill in the details, and the following bald statements of fact, extracted from Signor Giordani's work, may be allowed to speak for themselves. Of East Africa he writes :

In this part of Africa, as in other African colonies of Germany, the natives continued to revolt, partly stirred up by the Arabs, who, supported in their turn by the Sultan of Zanzibar, feared injury to their commerce, partly driven by the methods and behaviour of the Germans, who did not take local customs and conditions into account and conducted themselves as in a conquered country, parading their ownership. In 1890 the revolt, hitherto constant, was after various alternations of fortune quelled by Hermann von Wissmann.

\section{And of the Cameroons :}

It was soon necessary to send a military expedition to quell serious disorders, and the sloops Olga and Bismarck were sent to protect the imperial troops in the continued and sanguinary combats which they were obliged to wage along the coast. A year later, in 1885, the Germans were able to begin their explorations into the interior, and in 1892 they reached the Benue, after a long series of fierce contests with the natives, who for several years more and more frequently compelled the Germans to send armed forces at the cost of valuable lives. Still more bitterly contested was 
the last advance towards Lake Chad, where the Germans had been forestalled by the French, nor had German dominion any better fate in the regions along the coast. There, owing to the scanty ability displayed by successive governors, the discontent of the native traders showed itself openly, and the negroes of Dahomey, who constituted the police force, rose in rebellion. The revolt did not produce serious consequences, and the men of Dahomey were replaced by Sudanese.

There are two points touched upon in the last quoted passage that call for some comment. The discontent of the native traders here alluded to was occasioned by the inequitable German system which deliberately withheld from them all equality of commercial opportunity. To the European merchants was reserved the exclusive right of importing and exporting goods. Thus if a native desired to trade in articles of European manufacture, he was compelled to obtain his stock from the very men with whom in the retail business of the colony he was about to compete. In practice, of course, this meant that the white trader could always undersell him, and that the only course open to the native was to act as a salesman working on a commission for some European firm. Similarly, no native was allowed to export his own produce, but instead was compelled, if he would dispose of it at all, to sell it to an European, the white merchant being thus placed in a position of commanding advantage.

All this, of course, was in strict conformity with the German view that colonial possessions 
in Africa were to be maintained and developed for the exclusive benefit of Germans; but it was a system which successfully robbed the native inhabitants of those colonies of the last of the material advantages that might be expected to attend the establishment of a stable form of government in their midst. The more intelligent sections of the community bitterly resented being thus treated as serfs by strangers who had come into their country, not only uninvited and undesired, but in the face of a passionate resistance, and the experience had upon their energies a paralysing effect. No populous non-European country in the world has ever prospered unless its indigenous inhabitants have been at once contented and prosperous. This, however, is a fact which the Germans never appear to have appreciated, and their aggressive and expensive military policy, in combination with their shortsighted and selfish commercial system, sufficed to render insolvent even the richest of their colonial possessions, such as East Africa and the Cameroons. 


\section{XV}

ANother point of considerable importance remains to be noted. The German colonial system was in form and character a military despotism, merciless exploitation supported by overwhelming force constituting, in German eyes, the sole means whereby primitive peoples were to be governed, their countries developed, and the light of civilisation made to shine in the dark places of the earth. It was in miniature a practical application of the theories which have worked such ravages in Europe and throughout the world during the past four years; and it had for its foundation the characteristic German glorification of militarism. The superhumanity of the soldier, which was held to place him in some degree above the law to which common men conformed, was a conception which had been sedulously inculcated in Germany during the concluding thirty years of the nineteenth century, and it was perhaps only natural that German administrators should carry it with them to their colonies in Africa.

Now the experience of other European nations in primitive countries has taught very emphatically that the task of preventing the oppression of indigenous populations by natives who have been 106 
trained and armed by white men to act either as soldiers or as police is, in any circumstances, one of considerable difficulty. Abuse of authority by native subordinates of this type can only be checked by constant vigilance, by encouraging aggrieved persons freely to report any wrongs done to them, and by punishing misconduct with the utmost severity.

Any such line of action, however, was diametrically opposed to the German idea of what was due to the soldier. They regarded him as the incarnation of their authority, and they wished him to inspire fear, the distinction between fear and respect being one that is not very readily appreciated by the German mind. ${ }^{1}$ Accordingly the native soldiers in the German colonies constituted a privileged class, whose members were free to commit almost any excess without fear of punishment provided their victims were natives, and so long as they yielded an implicit obedience to their German masters. Thus was fashioned yet another scourge for the backs of the unhappy folk whom the European.Powers had handed over to the mercies of the Fatherland.

Native testimony is to be had in abundance of the fashion in which the African soldiers of Germany harried and oppressed them, but here it will perhaps suffice if a single illustration of their methods be cited. It is chosen because

1 Was it not loudly proclaimed in Berlin that the outrages committed in Belgium would inspire "respect" for the German army ? 
every detail connected with it is on official record.

In 1913 cases of yellow fever occurred in the Gold Coast, and these, in accordance with the provisions of an international convention, were duly notified to the governments of all neighbouring West African colonies. The government of Togoland forthwith placed a cordon of soldiers along a portion of its frontier to prevent any one passing over from the Gold Coast; but it failed to notify its own native population, or the British officers just across the boundary, of the action it had taken. Many of the natives of the Kwitta district in the Gold Coast cultivate land in Togoland, and are accustomed daily to cross the border to visit their farms.

No notice having reached them that the frontier was closed to them, a little party of natives attempted to pass the cordon, the very existence of which was unknown to them. The first thing that they knew was that fire was opened on them, and one of their number, an old woman, fell grievously wounded. Her only offence, be it remembered, was that she had attempted to pass a cordon of German native soldiers; but the ruffian who had shot her forthwith proceeded to club her to death with the butt end of his rifle. This is sufficiently illustrative of the methods which the native soldiers of Germany had been taught to regard as appropriate when dealing with the people of the country; but the really significant fact connected with this incident is that, though this brutal and senseless murder was 


\section{GERMAN INDIFFERENCE}

proved, the man who committed it was throughout supported by the German authorities at Lome, and neither compensation nor adequate apology was offered for this outrage perpetrated upon a British subject. 


\section{XVI}

ENovgr has now been said. We have seen how the European invasion of the non-European world, when in the sixteenth century it had passed beyond the stage of its first tentative gropings, had its beginning in aggression, violence and cruelty. We have seen how, in spite of certain temporary improvements in its character which were for the most part dictated by policy and expediency, European dominion continued until late in the eighteenth century to be conducted on purely selfish principles, and to be mainly a record of grievous injustice and ill-doing.

We have seen that the peoples of the nonEuropean world were originally regarded by white men as standing possessed of no rights of person or of property ; and how foreign to contemporary opinion, during a period of well nigh three hundred years, was the idea that the extension of European power and jurisdiction carried with it any duties or obligations towards the native populations subjected to them. We have seen how the first assertion of this principle emanated from the Commons of England, at the moment when Great Britain was standing on the very threshold of her immense empire in India; how she was the first of the European nations to declare that 


\section{PRINCIPLES OF COLONISATION 111}

expansion must mean the establishment of a reign of law to which rulers and ruled must alike submit themselves; that the employment of arbitrary or despotic methods of government by British administrators was illegal and inadmissible; and that "the largest and most generous construction" was to be placed by them upon native "laws, rights, usages, institutions and good customs."

We have marked how new was this conception of the duty owed by the white nations to the peoples of the non-European world, but how vigorously and persistently Great Britain championed it--how in its cause she risked apparent ruin and cheerfully submitted to great financial sacrifices, and this at a time when her predominant sea-power gave her so commanding a position throughout the non-European world that she was utterly free to take in these matters whatever course seemed good to her. We have seen, too, how that idea grew and gathered strength, until at the present time, in Great Britain and in the United States at any rate, all schools of political thought which command attention and respect are agreed that European power and jurisdiction in non-European lands find in the moral and material benefits which they confer upon the indigenous inhabitants their sole raison d'être and their one and only justification.

Thus, in the fullness of time, it has come to be accepted amongst us as axiomatic that where Europeans assume responsibility for the administration of territories inhabited by primitive and 
backward races, these lands must primarily be governed for the benefit of the native populations; that they must be freed from the payment of any tribute to the Mother Country, and must be allowed to devote their revenues to the development of their own resources; that they cannot, without gross injustice, be made to accord any special or exclusive privileges to Europeans; that the natives must be protected from unfair exploitation; and that upon them must be conferred the largest measure of personal freedom, peace, order, security and equality of opportunity. Such were the principles of colonial administration which Great Britain had successfully established throughout the length and breadth of her tropical dominions, and they were rapidly winning adherents in other lands by reason of the extraordinarily satisfactory results which attended their adoption.

Then, in an evil hour, impelled by no higher motive than a fierce hunger for possession, Germany shouldered her way into the colonial world, and in four years carved out for herself an immense empire in non-European lands. Forthwith the hands of time were thrust backward, and there began once more in the territories which an European nation had acquired a reign of tyranny and of brute force. Every wise and generous principle which experience had inculcated and the good conscience of other European nations had approved was straightway discarded.

We have seen her relying upon military might as the sole instrument wherewith to spread new 
ideas among primitive peoples, to wear down their opposition and to compel their sullen obedience. We have seen her bringing to these hapless folk not peace but a sword; not a reign of law, but a reign of terror; not even-handed justice, such as the most backward races are quick to understand and to appreciate, but the legalised oppression of innumerable petty tyrants. We have seen her exploiting her new possessions for the exclusive advantage of white men, and showing a cynical contempt for native rights and sentiments. We have seen her using her invincible power, not for the elevation of the native populations, by affording them increased opportunities for development and offering new achievements to their ambition, but employing it solely for purposes of conquest and repression. We have seen her, not conferring freedom, peace, security, happiness and contentment, but misery, bloodshed, oppression, slavery and an enduring sense of wrong.

This is Germany's record during her short reign over the fair and gracious territories in Africa which have now been torn from her grasp. We may thank God that throughout the Dark Continent "white men" and " Germans" are regarded and spoken of by the natives as two utterly distinct species of mankind; but the fact remains that during the past five and thirty years Germany has' besmirched the escutcheon of Europe in Africa with all the stains that of old befouled it during the first two centuries of the invasion of the non-European world by the nations of the West. 
The early conquerors were at least inspired by a high spirit of adventure, by dauntless courage and by an exalted faith in their mission. They faced tremendous odds and they enjoyed no such vast superiority of equipment over their opponents as belongs to the Europeans of our own day. Though they sinned greatly, they sinned after the manner of their age, and had for their excuse its comparative barbarism. It has been left to the Germans in Africa to reproduce, in infinitely more squalid circumstance, the crimes of the European conquerors of the sixteenth and seventeenth centuries. But they have throughout enjoyed perfect safety from any really effective retaliation, and they have had for their inspiration nothing more worthy than a gross material ambition. 


\section{XVII}

There is yet one more point that must be borne steadily in mind when the time arrives to determine the fate of the former colonies of Germany in Africa. Their native populations fared badly enough ere ever they had given to Germany any special or grievous cause for wrath. Since the outbreak of war, by welcoming the invading forces of the Allies and hailing them as their deliverers, they have offended in German eyes past all possibility of forgiveness. In many instances, chiefs and people alike have afforded active assistance to Germany's enemies, and have thereby irretrievably compromised themselves. They know what to expect if their former masters are suffered to return; and to-day the people of Europe and America cannot pretend that this knowledge is not shared by them in equal measure.

Will the white men in whom they have trusted deliver them to the torturers till all the debt be paid? Will the civilised world consent, as a mere matter of convenience and expediency, once more to surrender to so ruthless, so cruel, so selfish and so incompetent an exploiter of colonial territory the helpless people whom a war of Germany's own making has, for the moment, rescued from the grip of their oppressors? 
Those are the questions which the natives of Africa, in all the lands over which European rule extends, are asking themselves to-day. In their judgment the reputation of Europe and of the United States of America stands or falls by the answer that may be returned to them. 

RETURN TO the circulation desk of any

University of California Library

or to the

NORTHERN REGIONAL LIBRARY FACILITY

Bldg. 400, Richmond Field Station

University of California

Richmond, CA 94804-4698

ALL BOOKS MAY BE RECALLED AFTER 7 DAYS

2-month loans may be renewed by calling

(415) 642-6753

1-year loans may be recharged by bringing books to NRLF

Renewals and recharges may be made 4 days prior to due date

\section{DUE AS STAMPED BELOW}

NoV 271991

MAY 061993

AUTODISCCRC MAY 21 'S3

APR 132004 
U. C. BERKELEY LIBRARIES

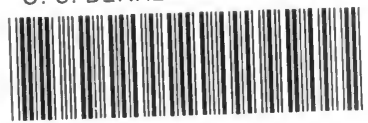

C042459209

\section{UNIVERSITY OF CALIFORNIA LIBRARY}


\%

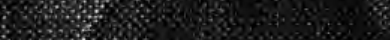

\%

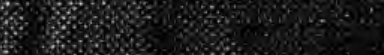

* $\%$ \%

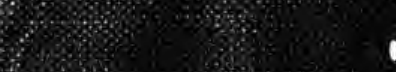

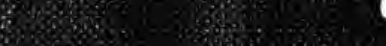

6.

(3)

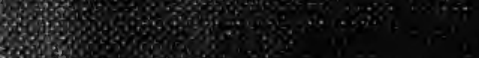

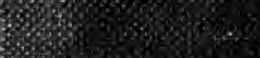

\%

20.80

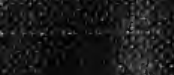

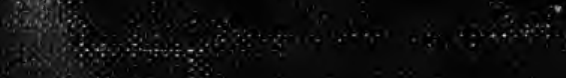

$=\frac{3}{30}$

- $-860 \%$

(x)

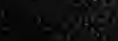
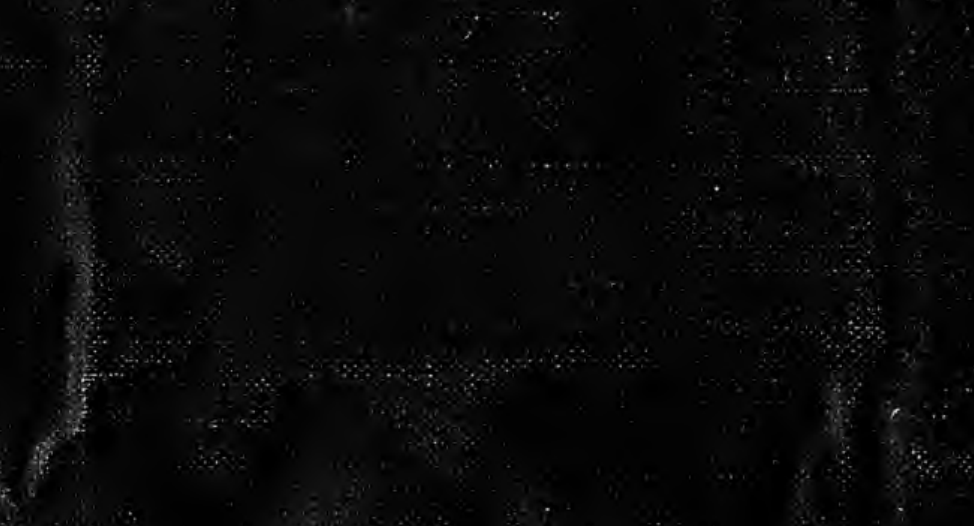

sotis

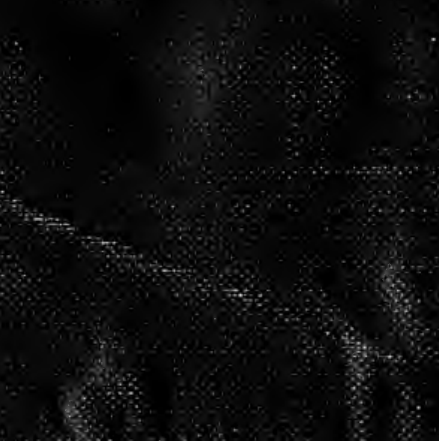

